Review

\title{
Emerging Role of Sphingosine-1-phosphate in Inflammation, Cancer, and Lymphangiogenesis
}

\author{
Wei-Ching Huang, Masayuki Nagahashi, Krista P. Terracina and Kazuaki Takabe* \\ Division of Surgical Oncology, Department of Surgery, Virginia Commonwealth University School of \\ Medicine and Massey Cancer Center, Richmond, VA 23298-0011, USA; \\ E-Mails: wchuang@vcu.edu (W.-C.H.); mnagahashi@vcu.edu (M.N.); \\ kmpennington@mcvh-vcu.edu (K.P.T.)
}

* Author to whom correspondence should be addressed; E-Mail: ktakabe @ vcu.edu; Tel.: +1-804-828-9322; Fax: +1-804-828-4808

Received: 11 June 2013; in revised form: 4 July 2013 / Accepted: 8 July 2013 /

Published: 23 July 2013

\begin{abstract}
The main function of the lymphatic system is to control and maintain fluid homeostasis, lipid transport, and immune cell trafficking. In recent years, the pathological roles of lymphangiogenesis, the generation of new lymphatic vessels from preexisting ones, in inflammatory diseases and cancer progression are beginning to be elucidated. Sphingosine-1-phosphate (S1P), a bioactive lipid, mediates multiple cellular events, such as cell proliferation, differentiation, and trafficking, and is now known as an important mediator of inflammation and cancer. In this review, we will discuss recent findings showing the emerging role of S1P in lymphangiogenesis, in inflammation, and in cancer.
\end{abstract}

Keywords: sphingolipids; sphingosine-1-phosphate; inflammation; lymphangiogenesis; cancer; lymphatic endothelial cell; VEGF; angiopoietin; spinster 2; metastasis

\section{Introduction}

The lymphatic system, composed of lymphatic vessels and lymphatic fluid, exerts important biological functions such as drainage of interstitial fluids and proteins to the blood stream and the transport of immune cells and nutrients [1]. Lymphangiogenesis is the process of formation of new lymphatic vessels from existing ones. Multiple signaling pathways orchestrate proliferation, sprouting and migration of lymphatic endothelial cells (LECs). Vascular endothelial growth factors (VEGF)-C 
and VEGF-D and their receptor (VEGFR-3) are the most studied proteins in lymphangiogenesis. In adulthood, lymphangiogenesis can occur when LECs are stimulated by inflammation- or tumor-associated factors. Sphingosine-1-phosphate (S1P), which is also upregulated in inflammation and in tumors, has recently gained attention as a mediator involved in lymphangiogenesis.

\section{Lymphatic System}

The circulatory system transports blood and lymphatic fluid in our body. Lymphatic fluid is defined as the fluid component within lymphatic vessels, containing interstitial fluid, macromolecules, and cells collected from the blood vascular system by lymphatic capillaries [2]. The lymphatic vasculature forms a unidirectional network commencing from peripheral tissue as blind-ended capillaries which then merge to pre-collecting vessels, collecting vessels, and finally, to afferent vessels to lymph nodes [3]. Lymphatic capillaries are composed of a thin-layer of oak leaf-shaped LECs, which have discontinuous button-like cell-cell junctions [4]. These intrajunctional gaps provide highly permeable sites for leukocyte entry and uptake of lymphatic fluid components. The main functions of the lymphatic vessel network are maintaining tissue fluid homeostasis, transporting lipids and nutrients, and immune cell trafficking [1]. Lymphatic vessels drain interstitial fluids from peripheral tissue into the thoracic duct, returning the fluid to the blood circulation and providing routes for immune cell trafficking [5,6]. The anatomy of lymphatic vasculature implies an important function for this system in immune cell trafficking. Abundance of lymphatic vessels in skin, airway, and gut - the sites frequently exposed to pathogens or environmental factors - indicates that the lymphatic system participates in the regulation of inflammatory responses through its role as the trafficking route for lymphocyte transport to the lymph nodes for immune surveillance [5]. Failure of lymphatic system function can cause lymphedema, excessive fluid accumulation in tissue, and alteration of immune responses [3,7].

\section{Regulators of Lymphangiogenesis}

Lymphangiogenesis is defined as the formation of new lymphatic vessels from existing ones. It occurs during embryonic development and becomes stable and quiescent after establishment of the lymphatic vasculature [3]. However, lymphangiogenesis can also be stimulated in adulthood to play physiological or pathological functions. It is known to occur in response to inflammatory conditions in peripheral tissues (skin, airway, and gut) and diseases such as inflammatory bowel diseases, rheumatoid arthritis, and cancer [8-11]. The regulation of lymphangiogenesis includes molecular mechanisms that are primarily mediated by growth factor-growth factor receptor systems (Table 1) and cellular mechanisms, predominantly involving myeloid cells. 
Table1. Growth factors involved in lymphangiogenesis.

\begin{tabular}{|c|c|c|}
\hline Growth factor & Receptor & Main function \\
\hline VEGF-A & VEGFR-2 & $\begin{array}{l}\text { - Recruit macrophage to facilitate inflammatory } \\
\text { lymphangiogenesis } \\
\text { - Generate giant and abnormal lymphatic vessels in cancer and } \\
\text { chronic inflammation }\end{array}$ \\
\hline VEGF-C & $\begin{array}{l}\text { VEGFR-2* } \\
\text { VEGFR-3 } \\
\text { Neuropilin-2 }\end{array}$ & $\begin{array}{l}\text { - Mediate embryonic lymphatic development } \\
\text { - Induce proliferation, migration, and } \\
\text { survival of lymphatic endothelial cells in inflammation and cancer }\end{array}$ \\
\hline VEGF-D & $\begin{array}{l}\text { VEGFR-2* } \\
\text { VEGFR-3 } \\
\text { Neuropilin-2 }\end{array}$ & $\begin{array}{l}\text { - Induce proliferation, migration, and } \\
\text { survival of lymphatic endothelial cells in inflammation and cancer }\end{array}$ \\
\hline Angiopoietin-1 & Tie2 & - Mediate post-natal lymphatic patterning \\
\hline Angiopoietin-2 & Tie2 & $\begin{array}{l}\text { - Mediate post-natal lymphatic patterning } \\
\text { - Might contribute to tumor-induced lymphangiogenesis }\end{array}$ \\
\hline
\end{tabular}

* After proteolytical processing, mature forms of VEGF-C and VEGF-D could bind to VEGFR-2.

\subsection{Vascular Endothelial Growth Factor (VEGF)/VEGFR System}

The discovery of vascular endothelial growth factors (VEGFs) and their receptors (VEGFRs) stemmed from angiogenesis research $[12,13]$. The mammalian VEGF family includes five members: VEGF (also called VEGF-A), placenta growth factor (PIGF), VEGF-B, VEGF-C, and VEGF-D. The VEGFR family includes VEGFR-1, VEGFR-2, and VEGFR-3. Typical signaling from VEGFRs promote cell survival, proliferation, and migration [14]. Among them, VEGF-C, VEGF-D, and their receptor VEGFR-3 are key regulators of lymphangiogenesis in both physiological and pathological settings and provided the first insights into how lymphangiogenesis occurs [7,15-21]. Overexpression of either VEGF-C or VEGF-D causes lymphangiogenesis; however, only VEGF-C is involved in embryonic lymphatic development [22-28]. VEGF-C expression is found at the sites of lymphatic sac formation in development as well as in vascular smooth muscles cells and lymph nodes in adults [25,29-31], while VEGF-D is only expressed in adult tissue such as the lungs, heart, skeletal muscle, and intestine [32].

A unique two-step proteolytic cleavage enables VEGF-C and VEGF-D precursor proteins to convert to active and mature forms and therefore determines their binding affinity to VEGFR-2 or VEGFR-3 [33,34]. Only fully processed mature forms can bind to VEGFR-2. The role of VEGFR-3 in lymphangiogenesis has been established in VEGFR-3-deficient mice, which have been shown to have a similar phenotype to VEGF-C-deficient mice [25,27]. In addition to VEGFRs, VEGF-C and VEGF-D also bind to neuropilin-2 (Nrp2), a semaphorin receptor in the nervous system that is also expressed in lymphatic capillaries [23]. Binding of Nrp2 modulates VEGFRs signaling by providing specificity of signal transduction [35-37]. Consistently, Nrp2-deficient mice have lymphatic 
hypoplasia [38]. Other than VEGF-C and VEGF-D, VEGF-A has also been shown to induce lymphangiogenesis in cancer [39] and chronically-inflamed tissue [40]. VEGF-A binds to VEGFR-2 to activate lymphangiogenesis; however, VEGF-A still cannot replace the role of VEGF-C in embryonic lymphatic development $[25,41]$. These reports strengthen the central role of VEGF-C in developmental lymphangiogenesis.

\subsection{Angiopoietin/Tie System}

In addition to the VEGF/VEGFR system, angiopoietins (Ang1, Ang2, and Ang3/4) and their receptors (Tie1 and Tie2) are also known as mediators for vascular vessel remodeling and integrity [42]. Tie1 and Tie2 are the only known endothelial cell-specific receptor tyrosine kinases [43,44]. Tie1-deficient mice showed compromised integrity of vessel endothelial cells and pulmonary edema and died in utero [45]. Mice with deficiency or loss-of-function Tie2 died in embryo due to inability to expand the vasculature system [46,47]. Ang1, Ang2, and Ang3/Ang4 have high sequence homology and all have been reported to promote lymphangiogenic sprouting [48-50]. Although all four of the angiopoietins have been shown to interact with Tie2 [51-53], Ang1 and Ang2 are the best characterized compared to the others to date. Ang1 is an obligate agonist of Tie2 receptor while Ang2 acts both as agonistic and as antagonistic in dose- and context-dependent manners [51,52,54]. Ang2 is persistently expressed in LECs, whereas Ang1 is downregulated by prospero-related homeodomain transcription factor (Prox-1) when blood vessel-derived endothelium is reprogrammed to lymphatic endothelium by Prox-1 [55,56]. In addition, Ang-2-deficient mice have shown lymphatic vasculature defects that can be rescued by Ang1 [54,57]. More studies are needed to further delineate the complexity of the interrelationship between Ang1 and Ang2.

\subsection{Myeloid Cells}

Myeloid cells including leukocytes and macrophages also have been shown to participate in lymphangiogenesis [58]. A role for macrophages in post-natal lymphatic vessels remodeling has been suggested in mice deficient of macrophage colony stimulatory factor (M-CSF), where lymphatic vessel branching is reduced due to absence of macrophages in these mice [8]. In the adulthood of these mice, however, no abnormality can be observed. B cells also regulate expansion of lymphatic system as observed in lymphocyte-deficient mice [59,60]. In response to inflammatory stimuli such as lipopolysaccharide (LPS) or TNF- $\alpha$, infiltrated macrophages express more VEGF-C and VEGF-D while LECs express higher Prox-1 and NF- $\kappa$ B to upregulate VEGFR-3 expression [61,62]. In a high-salt-diet-induced hypertension model, macrophages and dendritic cells are found to regulate the expansion of the lymphatic capillary network in skin through providing VEGF-C [63]. In various mouse tumor models, macrophage recruitment has been demonstrated to promote lymphangiogenesis [64-68]. Tumor-associated macrophages have also been linked to increased peri-tumoral lymphangiogenesis and metastasis in human cancer such as breast cancer [69], cervical cancer [65], squamous cell carcinoma [70], and advanced colorectal cancer [71]. Although still in debate, the general mechanism by which these macrophages, B cells, and dendritic cells contribute to lymphatic remodeling is through providing lymphangiogenic factors such as VEGF-A, VEGF-C, and VEGF-D. 


\section{Lymphangiogenesis during Development}

Lymphatic vascular development involves differentiation of LECs, lymphangiogenesis, and remodeling [3]. The blood vascular system develops earliest in embryos. Blood endothelial cells (BECs), differentiated from hemangioblast progenitors, form the primitive vascular plexus that is then remodeled into a vascular network. The first LECs are differentiated from a subpopulation of BECs in the cardinal vein and then sprout out to form primitive lymphatic sacs in regions where lymphangiogenic VEGF-C is expressed [3,25,72-74]. The distinct terminal differentiation between LECs and BECs enables the discovery of lymphatic vascular-specific markers such as Prox1, the membrane glycoprotein podoplanin (D2-40), VEGFR-3, and lymphatic vessel hyaluronan receptor-1 (LYVE-1) [7,75-78]. These main transcription factors, Sox18, COUP-TFII and Prox1, orchestrate LEC differentiation [72,79-83].

Once lymphatic sacs are formed, lymphatic vessels sprout from lymph sacs and then are remodeled into the lymphatic vascular network [6,76]. After embryonic development, functional lymphatic vasculature is established and quiescent. However, physical lymphangiogenesis in adults can occur in certain conditions, such as immunity [10,60,84-86], during wound healing [87,88], and at the sites of transplanted tissue [89-91]. Lymphangiogenesis helps to decrease inflammation-induced edema, and to transport extravasated leukocyte and antigen presenting cells from inflamed tissue to lymphoid organs to initiate specific immune responses [2,5].

\section{Lymphangiogenesis in Inflammation}

Although lymphangiogenesis is restricted to the site of inflamed tissue and wound healing in adulthood, pathological lymphangiogenesis also happens in the setting of dysregulated inflammatory responses or when cancer cells take advantage of lymphangiogenesis to facilitate their progression [6,92-99].

Lymphangiogenesis can be observed in inflamed peripheral tissue and its draining lymph nodes. Similar as in embryonic development, the VEGF-C/VEGFR-3 axis has been identified as a key mediator of inflammation-driven lymphangiogenesis as described in the model of cornea neovascularization [100]. In a mouse airway infection model, VEGF-C and VEGF-D-expressing immune cells drive lymphangiogenesis. Another mouse peritonitis model showed inflammatory lymphangiogenesis is triggered through NF- $\kappa \mathrm{B}$-mediated upregulation of Prox-1 and VEGFR-3 [62]. Inflammation promotes lymphatic vessel growth by pro-inflammatory cytokines like TNF- $\alpha$ and IL- $1 \beta$ which upregulate VEGF-C though NF- $\kappa \mathrm{B}$-mediated promoter activation [101]. The relationship between lymphangiogenesis and inflammation is somewhat reciprocal. Lymphangiogenesis has a physical role in the clearance of fluid and infiltrated inflammatory mediators to resolve inflammation as it does in tissue repair and wound healing; however, pervasive lymphangiogenesis in response to overexpressed VEGF-C or VEGF-A could delay lymphatic fluid clearance as well [41,102]. It has been observed that once lymphangiogenesis has been established during inflammation, the newly formed lymphatic vessels persist for months even when the inflammation has been resolved [8]. This might be an important clue for the pathological involvement of lymphangiogenesis in chronic inflammatory diseases. 
In addition to the VEGF-C/VEGFR-3 axis, VEGF-A expression is also upregulated in certain inflammatory circumstances such as rheumatoid arthritis and delayed-type hypersensitivity; however, VEGF-A and VEGFR1/2 seem to participate in lymphangiogenesis in a more context-dependent way. In a TNF- $\alpha$-induced rheumatoid arthritis model, lymphangiogenesis was reduced by neutralization of VEGFR-2 [103]. In a delayed-type hypersensitivity model, which is induced in the ear skin of transgenic mice that overexpress VEGF-A specifically in the epidermis [9], the inflammatory lesions displayed promoted lymphatic vessel proliferation and enlargement, which might contribute to prolonged inflammatory responses, by blocking both VEGFR-1 and VEGFR-2 suppressed lymphangiogenesis as well as inflammation. Nonetheless, no significant effect on lymphangiogenesis was observed by inhibiting either VEGFR-1 or VEGFR-2 in a bacterial infection-induced chronic airway inflammation model [8].

The involvement of myeloid cells in inflammatory lymphangiogenesis is also commonly observed. For example, B cells are found to drive lymphangiogenesis in inflamed lymph nodes [60]. In a murine corneal inflammation model, a rapid increase of VEGFR-3 and VEGF-C expressing dendritic cells are found in the cornea [104]. Macrophages are recruited to inflamed corneas in response to VEGF-A, and to release VEGF-C and VEGF-D to mediate inflammatory lymphangiogenesis in a rabbit corneal inflammation model [100].

\section{Lymphangiogenesis in Cancer}

Tumor-associated lymphangiogenesis has been observed and implicated in cancer progression by its role of providing routes for immune cell recruitment and for cancer metastasis [92,105,106]. It has been shown that tumor-associated lymphangiogenesis usually causes formation of abnormal and leaky lymphatic vessels, which facilitates access for cancer cells to metastasize [107,108]. As in developmental lymphangiogenesis, transcription factors Sox18 and COUP-TFII and the VEGF-C/VEGFR-3/Nrp2 system are utilized by tumor cells to regulate LEC differentiation and lymphatic vessel sprouting, respectively. Usually, the expression of Sox18 and COUP-TFII is suppressed after development; however, studies have indicated that these proteins might be re-expressed by tumor cells to facilitate lymphangiogenesis and metastasis. In experimental tumor models, Sox18 deficiency or COUP-TFII inactivation has been shown to cause reduced tumor lymphangiogenesis and metastasis [109,110]. COUP-TFII might exert its lymphangiogenic function through Nrp2-increased VEGF-C signaling [109].

Studies have demonstrated that VEGF-C and VEGF-D induce lymphangiogenesis, lymphatic invasion, and nodal metastasis in various experimental tumor models [92,111-119]. Collaborative action of VEGF-C and another growth factor, fibroblast growth factor-2 (FGF-2), has also been reported [120]. Reciprocally, blocking VEGFR-3, Nrp2, or FGF-2 has been shown to inhibit tumor growth, lymphaniogensis, and metastasis [37,115,121,122].

Early stage of tumorigenesis requires involvement of Ang2 as demonstrated in Ang2-deficient mice [123]. Moreover, Ang2/Tie2 signaling has been implicated in tumor-induced angiogenesis and tumor growth and metastasis [124,125]. Further studies will be needed to further delineate the contribution of the Ang2/Tie2 system in tumor-induced lymphangiogenesis. The involvement of myeloid cells in tumor-induced angiogenesis is still a matter of debate. Some evidence exists for trans- 
differentiation of hematopoietic cell-derived endothelial progenitors to leukocytes and macrophages precipitating the process of growing vessels in tumor [58], while other reports show no evidence for the contribution of either bone marrow-derived cells or macrophages [126,127].

\section{Sphingosine-1-phosphate (S1P)}

Sphingosine-1-phosphate (S1P) is a bioactive lipid involved in a broad spectrum of cellular process such as cell survival, proliferation, differentiation, migration, and trafficking $[128,129]$. S1P is formed in cells by phosphorylation of sphingosine by sphingosine kinases (SphK1 and SphK2). Breakdown of S1P can be achieved by irreversible hydrolysis by S1P lyase or reversible dephosphorylation by S1P phosphatases (SPP1 and SPP2) back to sphingosine [130]. Intracellular S1P is a second messenger to trigger calcium release from the endoplasmic reticulum [131-133]. Important intracellular target proteins of S1P such as histone deacetylases (HDACs) and tumor necrosis factor (TNF)-associated factor 2 (TRAF2) have been identified [134,135]. These findings further address the molecular mechanisms by which S1P mediates TNF- $\alpha$ signaling and epigenetic regulation.

Intracellular S1P can be exported by several transporters, such as the ATP-binding cassette transporters ABCA1 [136], ABCC1 [137,138], ABCG2 [138], and Spinster 2 (Spns2) [139-147]. Interestingly, $\mathrm{ABCC} 1$ and $\mathrm{ABCG} 2$ were originally identified as multi-drug resistant genes [138], and correlate with worse prognosis in breast cancer [148]. Discovery of these S1P transporters explains the diverse autocrine and paracrine actions of S1P. The "inside-out signaling" of S1P is termed to describe that activation of SphK1 produces S1P which is exported and then binds to five specific G-proteincoupled receptors, S1PRs (S1PR1-5) [129]. The combination and cell-type-specific expression of different S1PRs determines a broad range of biological functions mediated by S1P $[129,149,150]$. Owing to its multiple biological functions, S1P is implicated in various physiological and pathological conditions such as inflammation and cancer [128,150,151].

\section{S1P in Inflammation}

S1P is now emerging as an important mediator of multiple aspects of both innate and adaptive immunity $[149,150]$. One of the most important functions of S1P is regulation of immune cell trafficking. Concentration of S1P in the blood is much higher than within the tissue, and this S1P gradient is important for lymphocyte trafficking [150,152]. Lymphocytes sense this S1P gradient, and by altering S1PRs expression, egress from lymphoid organs to the blood [153-156]. Ample evidence of S1P's role has been collected in experiments using mice with genetic loss of S1PR1 [157,158] as well as in models that have downregulation of S1PR1 by using a functional antagonist of S1PR1, FTY720, which is an FDA-approved drug for treatment of multiple sclerosis [159]. FTY720 is a structural analog of S1P that will be phosphorylated by SphK1 or SphK2 and produce phosphorylatedFTY720 (FTY720-P) [160-162]. FTY720-P binds to all the S1PRs except for $\mathrm{S}_{2} \mathrm{P}_{2}$, acting as a functional antagonist. FTY720-P induces internalization and degradation of the S1PR1 therefore affecting lymphocyte trafficking by decreasing the number of mature circulating lymphocytes and preventing lymphocyte egress from lymphoid organs [163-165]. This unique action is what makes FTY720 an immunosuppressive agent for treating the autoimmune disease multiple sclerosis. Preclinical 
evidence is still accumulating in other inflammatory disease such as colitis [166], arthritis [167], and asthma [168].

Furthermore, the intracellular actions of S1P also play important role in inflammation by activation of the transcription factor NF- $\kappa \mathrm{B}$, which is required in inflammatory and immune responses $[134,169]$. S1P has been shown to mimic the effect of the inflammatory cytokine TNF- $\alpha$ to activate endothelial cell activation through NF- $\kappa \mathrm{B}$ [170]; subsequently, the biological action of TNF- $\alpha$ has been shown to occur through activation of SphK1. Furthermore, SphK1 has proven to be an indispensable mediator in LPS, TNF- $\alpha$, and IL- $\beta$ signaling and pro-inflammatory function [171-173].

\section{S1P in Cancer Progression}

The role of S1P in cancer progression has been established by studies demonstrating that the upregulation/activation of SphK1 and production of S1P inhibits apoptosis and facilitates survival of cancer cells, thus promoting tumor growth, angiogenesis, and metastasis [151,174]. Numerous studies reveal the oncogenic role of SphK1; however, the isoform SphK2 seems to possess not only an overlapping role with SphK1 in promoting tumor development but also an opposing role in inducing apoptosis $[175,176]$. The mechanism by which SphK2-produced S1P acts as an endogenous HDAC inhibitor [135] might suggest a more sophisticated role of SphK2 in cancer progression due to the varied contexts of epigenetic regulation among different cell types. In solid tumors, SphK1 is required in the oncogenic signaling of VEGF, epidermal growth factor (EGF), and Ras [177-179]. Overexpression of SphK1 has been identified in mRNA screening or immunohistochemistry staining in multiple cancer cells derived from breast, colon, lung, ovary, stomach, uterus, kidney, and rectum [180-182]. Inhibition of SphK1 with its specific inhibitor SK1-I reduces the growth of acute myelogenous leukemia and glioblastoma [183,184]. A recent study has proposed a new SphK2 specific inhibitor ABC294640 [185] which reduces S1P levels and inhibits cancer cells proliferation in vitro and in vivo, and might be used to further dissect the biological functions between the two isoforms.

As discussed above, cancer cells may adapt both the intracellular actions of S1P and inside-out signaling of S1P to promote their survival and metastasis. S1P may act on intracellular targets such as HDACs and NF- $\mathrm{KB}$ to promote cancer progression [134,135]. Tumor cells export S1P to act through S1PRs to promote growth, survival, motility and metastasis in an autocrine manner [186,187]. A paracrine action of tumor cells-exported-S1P is to induce the production of endothelial adhesion molecules, angiogenesis, and to regulate tumor-stromal interactions as well as immune cells [188].

S1PR1 has been shown to mediate persistent activation of signal transducer and activator of transcription-3 (STAT3) in tumor. Activated STAT3 therefore plays two regulatory roles as transcription factor for both S1PR1 and IL-6, which is the most potent oncogenic cytokine [189]. In agreement with this report, our recent study further demonstrates the SphK1/S1P/S1PR1 axis links STAT3 and NF- $\kappa$ B persistent activation in colitis-associated colon cancer [190].

\section{Role of S1P in Lymphangiogenesis}

The role of S1P in determining the fate of vascular cells is much known, mainly through interaction of S1PRs, which are coupled with different combinations of G proteins. S1PR1 couples with the Gi protein family, while S1PR2 and S1PR3 couple to the $G_{i}, G_{q}$, and $G_{12 / 13}$ protein families. S1P regulates 
vascular endothelial cell proliferation, migration, and morphogenesis. S1PR1-deficient mice have been shown to have incomplete vascular maturation, dying in embryo due to hemorrhage [157]. S1PR1-mutant cells have shown an inability to activate the small GTPase, Rac, therefore leading to a defective migration response. Attempts to block S1PRs by FTY720 or extracellular S1P by anti-S1P-neutralizing antibody have resulted in an inhibition of tumor-induced angiogenesis [191,192]. Together, this evidence highlights the essential role of S1PR1 and S1P signaling in blood vessel formation and mammalian development. Regarding the close similarity of regulation and intimate crosstalk of angiogenesis and lymphangiogenesis, a role for S1P in lymphangiogenesis has been expected [193].

Following from the various overlapping roles of S1P and lymphangiogenesis in physical and pathological contexts, studies to address their interrelationship have been accumulating during the past five years [194]. As summarized in Figure 1, Yoon et al. first depicted the elegant signaling pathways by which S1P promotes lymphangiogenesis via an S1PR1-dependent manner [195]. Since S1P has been shown to possess angiogenic and pro-inflammatory properties [196,197], a lymphangiogenic action is therefore hypothesized. Yoon et al. demonstrated that exogenous S1P induces lymphangiogenesis in both in vitro and in vivo systems. By treating human primary LECs with exogenous S1P and positive control VEGF-C, they found S1P induced migration and tube formation, but not proliferation of LECs. In vivo evidence was collected by the Matrigel plug assay, where S1P has been shown to act similarly to VEGF-C, inducing significant lymphangiogenesis. The molecular mechanism has been further addressed in studies using the genetic silencing of S1PR1 or S1PR3, where S1PR1, but not S1PR3, has been shown to be required in the lymphangiogenic action of S1P. S1P activates S1PR1; therefore, its coupled-Gi protein is activated to stimulate downstream phospholipase $\mathrm{C}$ to mobilize calcium to induce in vitro lymphangiogenesis.

Figure 1. Sphingosine-1-phosphate (S1P) in cancer-induced lymphangiogenesis.

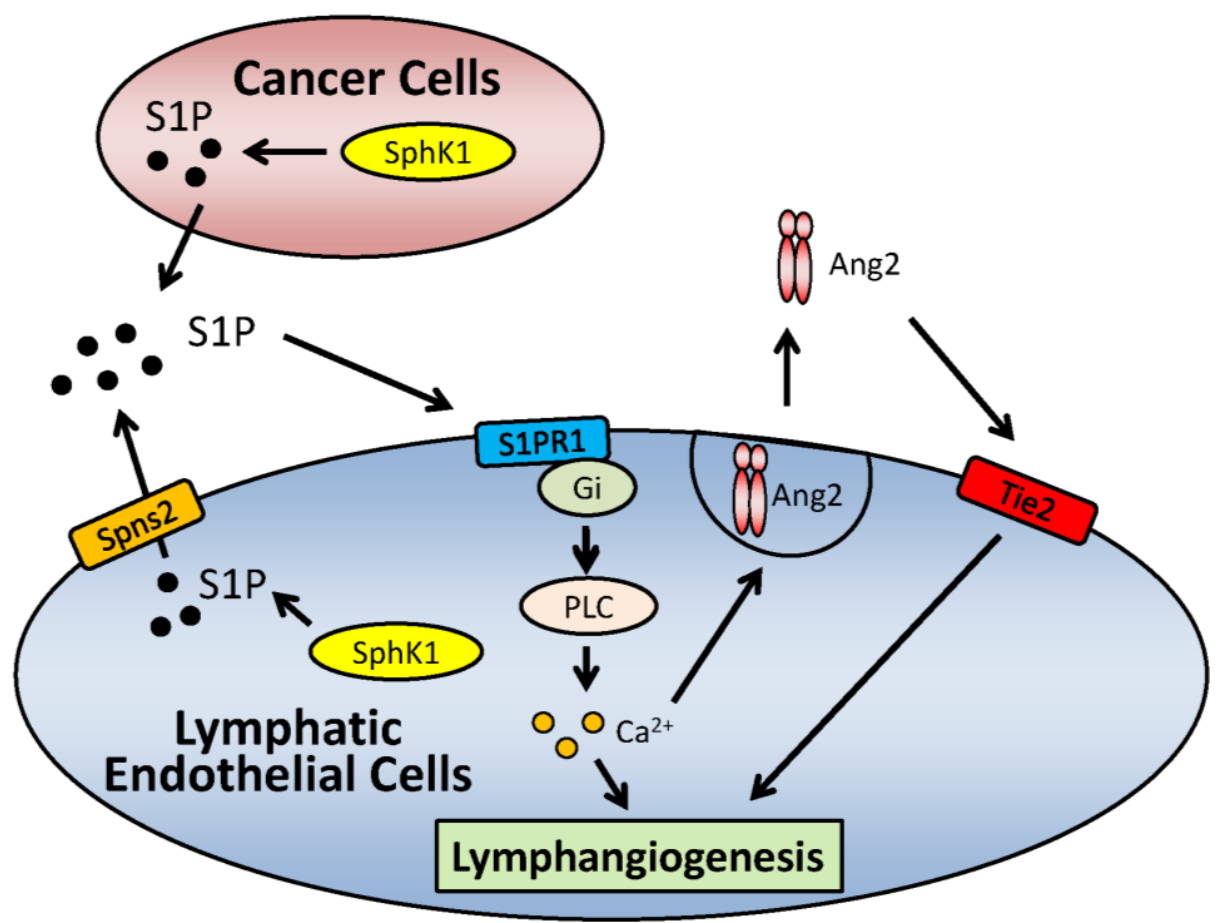


Given the role of Ang2 in lymphatic vessel development [54], Jan et al. further provided a link between S1P and Ang2 (Figure 1). Exogenous S1P treatment was shown to stimulate Ang2 exocytosis by either BECs or LECs. In agreement with Yoon et al.'s work, S1P acts through an S1P1/Gi/phospholipase C/Calcium signaling pathway to trigger Ang2 exocytosis [198]. Moreover, our group recently reported that SphK1-produced S1P promotes angiogenesis and lymphangiogenesis and facilitates breast cancer progression [199]. Because lymphatic metastasis is a major determinant for the staging and prognosis of breast cancer [200,201] and due to the importance of SphK1 in cancer progression as discussed above, we used an improved syngeneic breast cancer cell implantation method to examine the effect of SphK1 specific inhibitor, SK1-I, on tumor-induced lymphangiogenesis and cancer progression. In this model, we found inhibition of SphK1 decreases tumor growth, tumor burden, as well as lung metastasis. S1P levels and lymphangiogenesis in tumor are lowered by treatment with SphK1 inhibitor. We further demonstrated S1P acts similarly with Ang2 to exert angiogenic and lymphangiogenic effects on BECs and LECs. SphK1 inhibitor was shown to further abrogate the effect of Ang2. These results indicate that targeting S1P is a feasible therapeutic strategy for breast cancer and also shed light on the pathological effect of S1P in tumor-induced lymphangiogenesis.

To address the function of S1P in lymphatic system development [141], Pham et al. used an advanced animal model - SphK2 knockout mice with LEC-specific deletion of SphK1 ( $\mathrm{SphK}^{\Delta}$ mice). This sophisticated model was necessitated by the fact that SphK1 and SphK2 double knockout mice die in utero due to defects in blood vascular angiogensis and neurogenesis [202], whereas, SphK1-deficient or SphK2-deficient mice appeared morphologically and functionally normal [203]. Pham et al. found undetectable amounts of S1P in lymphatic fluid and no difference in blood S1P in their $\mathrm{SphK}^{\Delta}$ mice compared to control mice. This ablation of lymphatic fluid S1P leads to aberrant lymphocyte trafficking and altered lymphatic vasculature. Along with this report, our group demonstrated the importance of S1P in the lymphatic system by examining Spns2-deficient mice [140]. We found aberrant lymphocyte trafficking and also a disrupted lymphatic vessel network in Spns2-deficient mice. Interestingly, Spns2-deficient mice showed decreased S1P in blood but increased concentrations in lymphatic fluid. Clearly, more work is needed to detangle the interrelationship between S1P production and exportation and the resultant impact on lymphatic system development.

Recently, it has been reported that S1P in the blood circulation stimulates S1PR1 on the blood endothelial cells, which restricts sprouting angiogenesis, enhances the cell-to-cell adhesion, and stabilizes the vessels in the development process [204-207] (Figure 2A). Decreased expression of S1PR1 results in more aberrant sprouting, which actually interferes with vascular development and results in immature vascular networks in an S1PR1 knockout mouse model as well as in a model using morpholio-mediated knockdown of S1PR1 in a zebra fish [158,207]. Therefore, it is important to note that $\mathrm{S} 1 \mathrm{P}$ regulates the vascular maturation in the development process by suppressing unnecessary sprouting and increasing the endothelial cell contact. Interestingly, it was recently shown that S1PR1 and S1PR2 cooperate to regulate the vascular development [207]. Moreover, Spns2, a newly identified S1P transporter, also cooperates with S1PR1 in this process [207], and as discussed above, we recently found that Spns2 has a role in lymphatic vessel network development as well [140]. Although roles for S1P in vessel sprouting in lymphangiogenesis and in lymphatic vessel stabilization are yet to be reported, S1P is expected to have a similar role in the development process of lymphatic vessels to its 
role in that of blood vessels considering that Pham et al. have reported that S1P secreted from lymphatic endothelial cells regulates lymphatic vessel maturation [141]. Furthermore, the role of S1P in tumor-induced angiogenesis and lymphangiogenesis needs to be investigated more precisely in this context; since S1P is provided not only from blood and endothelial cells, but also from tumors [199], and the contribution of S1P in the angiogenesis and lymphangiogenesis induced by tumors may be different from that which occurs in the normal vascular development processes (Figure 2B). In sum, S1P and S1PR1 regulate vascular development processes by restricting aberrant sprouting and stabilizing the vessels. Further investigation needs to be done especially in the cancer field.

These studies have firmly linked S1P to lymphangiogenesis in either molecular or biological aspects. Therefore, S1P might be a potential new addition to the growing list of lymphangiogenic factors secreted by LECs, inflammatory cells, and cancer cells to orchestrate the development and function of lymphatic system.

Figure 2. S1P and sprouting angiogenesis in normal development and in tumor-induced angiogenesis.

A

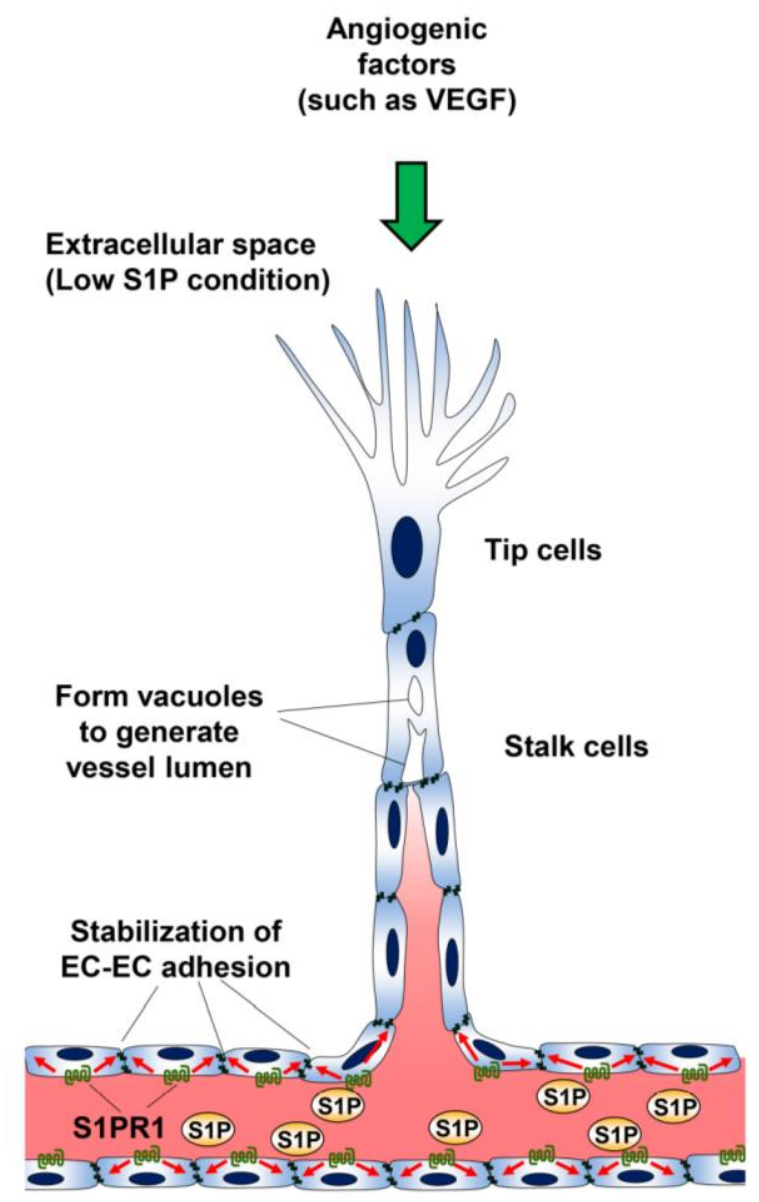

B

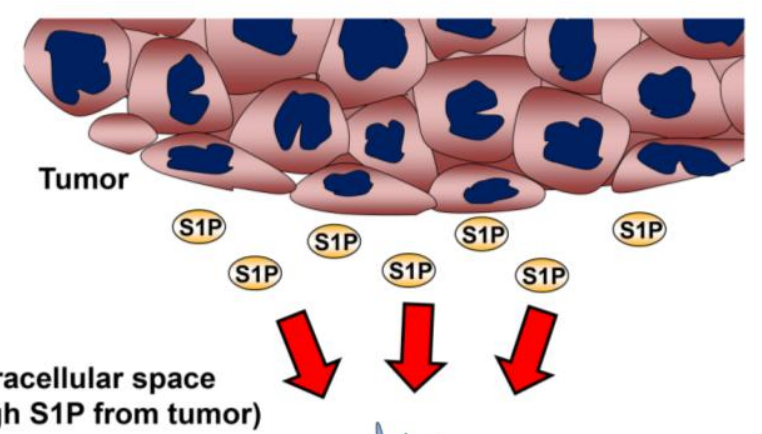

(High S1P from tumor)
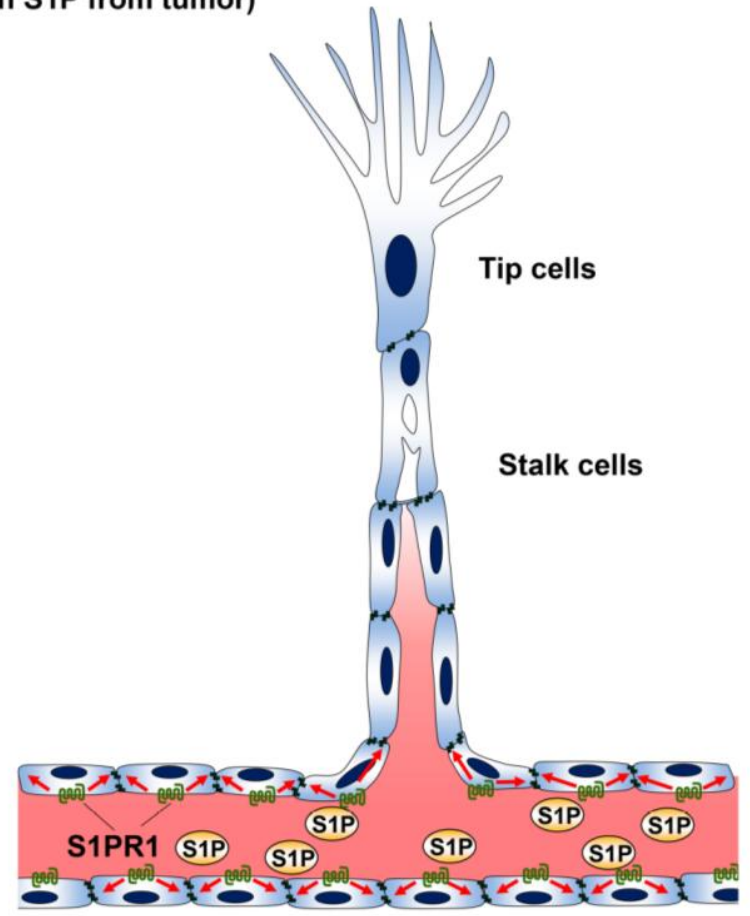


\section{Conclusions}

The lymphatic system contributes to important physiologic functions in fluid homeostasis, lipid transport, and in immune cell trafficking. Dysregulation of lymphangiogenesis provides a niche for uncontrolled inflammation and cancer progression. The field of lymphatic biology research remains young and needs more attention. Owing to the involvement of S1P in a wide range of physical and pathological process, the link between S1P and lymphangiogenesis provides important insight for further exploration of this field. Moreover, the emerging role of S1P as a lymphangiogenic lipid unveils the hidden regulatory mechanism which LECs, immune cells, or cancer cells utilize for promoting lymphangiogenesis in the context of inflammation and cancer. For therapeutic purposes, targeting S1P and S1P-metabolizing enzymes might be a feasible strategy. However, due to the massive complexity in the signaling pathways leading to lymphangiogenesis, more studies are still needed to establish an S1P pathway targeted therapy.

\section{Acknowledgement}

Kazuaki Takabe is supported by United States National Institute of Health (R01CA160688) and Susan G. Komen for the Cure (Investigator Initiated Research Grant (IIR12222224)). Masayuki Nagahashi is a Japan Society for the Promotion of Science Postdoctoral Fellow.

\section{Conflict of interest}

The author declares no conflict of interest.

\section{References}

1. Swartz, M.A. The physiology of the lymphatic system. Adv. Drug Deliv. Rev. 2001, 50, 3-20.

2. Rovenska, E.; Rovensky, J. Lymphatic vessels: Structure and function. Israel Med. Assoc. J. IMAJ 2011, 13, 762-768.

3. Schulte-Merker, S.; Sabine, A.; Petrova, T.V. Lymphatic vascular morphogenesis in development, physiology, and disease. J. Cell. Biol. 2011, 193, 607-618.

4. Baluk, P.; Fuxe, J.; Hashizume, H.; Romano, T.; Lashnits, E.; Butz, S.; Vestweber, D.; Corada, M.; Molendini, C.; Dejana, E.; et al. Functionally specialized junctions between endothelial cells of lymphatic vessels. J. Exp. Med. 2007, 204, 2349-2362.

5. Randolph, G.J.; Angeli, V.; Swartz, M.A. Dendritic-cell trafficking to lymph nodes through lymphatic vessels. Nat. Rev. Immunol. 2005, 5, 617-628.

6. Alitalo, K.; Tammela, T.; Petrova, T.V. Lymphangiogenesis in development and human disease. Nature 2005, 438, 946-953.

7. Tammela, T.; Alitalo, K. Lymphangiogenesis: Molecular mechanisms and future promise. Cell 2010, 140, 460-476.

8. Baluk, P.; Tammela, T.; Ator, E.; Lyubynska, N.; Achen, M.G.; Hicklin, D.J.; Jeltsch, M.; Petrova, T.V.; Pytowski, B.; Stacker, S.A.; et al. Pathogenesis of persistent lymphatic vessel hyperplasia in chronic airway inflammation. J. Clin. Invest. 2005, 115, 247-257. 
9. Kunstfeld, R.; Hirakawa, S.; Hong, Y.K.; Schacht, V.; Lange-Asschenfeldt, B.; Velasco, P.; Lin, C.; Fiebiger, E.; Wei, X.; Wu, Y.; et al. Induction of cutaneous delayed-type hypersensitivity reactions in VEGF-A transgenic mice results in chronic skin inflammation associated with persistent lymphatic hyperplasia. Blood 2004, 104, 1048-1057.

10. Kajiya, K.; Detmar, M. An important role of lymphatic vessels in the control of UVB-induced edema formation and inflammation. J. Invest. Dermatol. 2006, 126, 919-921.

11. Zhang, Q.; Lu, Y.; Proulx, S.T.; Guo, R.; Yao, Z.; Schwarz, E.M.; Boyce, B.F.; Xing, L. Increased lymphangiogenesis in joints of mice with inflammatory arthritis. Arthritis Res. Ther. 2007, 9, R118.

12. Shibuya, M. Vascular endothelial growth factor and its receptor system: Physiological functions in angiogenesis and pathological roles in various diseases. J. Biochem. 2013, 153, 13-19.

13. Lohela, M.; Bry, M.; Tammela, T.; Alitalo, K. VEGFs and receptors involved in angiogenesis versus lymphangiogenesis. Curr. Opin. Cell Biol. 2009, 21, 154-165.

14. Olsson, A.K.; Dimberg, A.; Kreuger, J.; Claesson-Welsh, L. VEGF receptor signalling-in control of vascular function. Nat. Rev. Mol. Cell. Biol. 2006, 7, 359-371.

15. Pepper, M.S.; Skobe, M. Lymphatic endothelium: Morphological, molecular and functional properties. J. Cell. Biol. 2003, 163, 209-213.

16. Karpanen, T.; Alitalo, K. Molecular biology and pathology of lymphangiogenesis. Annu. Rev. Pathol. 2008, 3, 367-397.

17. Alitalo, K. Growth factors controlling angiogenesis and lymphangiogenesis. Ugeskrift Laeger 2002, 164, 3170-3172.

18. Kaipainen, A.; Korhonen, J.; Mustonen, T.; van Hinsbergh, V.W.; Fang, G.H.; Dumont, D.; Breitman, M.; Alitalo, K. Expression of the fms-like tyrosine kinase 4 gene becomes restricted to lymphatic endothelium during development. Proc. Natl. Acad. Sci. USA 1995, 92, 3566-3570.

19. Saaristo, A.; Karkkainen, M.J.; Alitalo, K. Insights into the molecular pathogenesis and targeted treatment of lymphedema. Ann. N.Y. Acad. Sci. 2002, 979, 94-110.

20. Makinen, T.; Jussila, L.; Veikkola, T.; Karpanen, T.; Kettunen, M.I.; Pulkkanen, K.J.; Kauppinen, R.; Jackson, D.G.; Kubo, H.; Nishikawa, S.; et al. Inhibition of lymphangiogenesis with resulting lymphedema in transgenic mice expressing soluble VEGF receptor-3. Nat. Med. 2001, 7, 199-205.

21. Joukov, V.; Pajusola, K.; Kaipainen, A.; Chilov, D.; Lahtinen, I.; Kukk, E.; Saksela, O.; Kalkkinen, N.; Alitalo, K. A novel vascular endothelial growth factor, VEGF-C, is a ligand for the Flt4 (VEGFR-3) and KDR (VEGFR-2) receptor tyrosine kinases. EMBO J. 1996, 15, 290-298.

22. Tammela, T.; Saaristo, A.; Holopainen, T.; Lyytikka, J.; Kotronen, A.; Pitkonen, M.; Abo-Ramadan, U.; Yla-Herttuala, S.; Petrova, T.V.; Alitalo, K. Therapeutic differentiation and maturation of lymphatic vessels after lymph node dissection and transplantation. Nat. Med. 2007, 13, 1458-1466.

23. Karkkainen, M.J.; Saaristo, A.; Jussila, L.; Karila, K.A.; Lawrence, E.C.; Pajusola, K.; Bueler, H.; Eichmann, A.; Kauppinen, R.; Kettunen, M.I.; et al. A model for gene therapy of human hereditary lymphedema. Proc. Natl. Acad. Sci. USA 2001, 98, 12677-12682. 
24. Saaristo, A.; Veikkola, T.; Tammela, T.; Enholm, B.; Karkkainen, M.J.; Pajusola, K.; Bueler, H.; Yla-Herttuala, S.; Alitalo, K. Lymphangiogenic gene therapy with minimal blood vascular side effects. J. Exp. Med. 2002, 196, 719-730.

25. Karkkainen, M.J.; Haiko, P.; Sainio, K.; Partanen, J.; Taipale, J.; Petrova, T.V.; Jeltsch, M.; Jackson, D.G.; Talikka, M.; Rauvala, H.; et al. Vascular endothelial growth factor C is required for sprouting of the first lymphatic vessels from embryonic veins. Nat. Immunol. 2004, 5, 74-80.

26. Veikkola, T.; Jussila, L.; Makinen, T.; Karpanen, T.; Jeltsch, M.; Petrova, T.V.; Kubo, H.; Thurston, G.; McDonald, D.M.; Achen, M.G.; et al. Signalling via vascular endothelial growth factor receptor-3 is sufficient for lymphangiogenesis in transgenic mice. EMBO J. 2001, 20, $1223-1231$.

27. Haiko, P.; Makinen, T.; Keskitalo, S.; Taipale, J.; Karkkainen, M.J.; Baldwin, M.E.; Stacker, S.A.; Achen, M.G.; Alitalo, K. Deletion of vascular endothelial growth factor C (VEGF-C) and VEGF-D is not equivalent to VEGF receptor 3 deletion in mouse embryos. Mol. Cell. Biol. 2008, 28, 4843-4850.

28. Baldwin, M.E.; Halford, M.M.; Roufail, S.; Williams, R.A.; Hibbs, M.L.; Grail, D.; Kubo, H.; Stacker, S.A.; Achen, M.G. Vascular endothelial growth factor D is dispensable for development of the lymphatic system. Mol. Cell. Biol.2005, 25, 2441-2449.

29. Kukk, E.; Lymboussaki, A.; Taira, S.; Kaipainen, A.; Jeltsch, M.; Joukov, V.; Alitalo, K. VEGF-C receptor binding and pattern of expression with VEGFR-3 suggests a role in lymphatic vascular development. Development 1996, 122, 3829-3837.

30. Partanen, T.A.; Arola, J.; Saaristo, A.; Jussila, L.; Ora, A.; Miettinen, M.; Stacker, S.A.; Achen, M.G.; Alitalo, K. VEGF-C and VEGF-D expression in neuroendocrine cells and their receptor, VEGFR-3, in fenestrated blood vessels in human tissues. FASEB J. 2000, 14, 2087-2096.

31. Lymboussaki, A.; Olofsson, B.; Eriksson, U.; Alitalo, K. Vascular endothelial growth factor (VEGF) and VEGF-C show overlapping binding sites in embryonic endothelia and distinct sites in differentiated adult endothelia. Circ. Res. 1999, 85, 992-999.

32. Achen, M.G.; Jeltsch, M.; Kukk, E.; Makinen, T.; Vitali, A.; Wilks, A.F.; Alitalo, K.; Stacker, S.A. Vascular endothelial growth factor D (VEGF-D) is a ligand for the tyrosine kinases VEGF receptor 2 (Flk1) and VEGF receptor 3 (Flt4). Proc. Natl. Acad. Sci. USA 1998, 95, 548-553.

33. Joukov, V.; Sorsa, T.; Kumar, V.; Jeltsch, M.; Claesson-Welsh, L.; Cao, Y.; Saksela, O.; Kalkkinen, N.; Alitalo, K. Proteolytic processing regulates receptor specificity and activity of VEGF-C. EMBO J. 1997, 16, 3898-3911.

34. Stacker, S.A.; Stenvers, K.; Caesar, C.; Vitali, A.; Domagala, T.; Nice, E.; Roufail, S.; Simpson, R.J.; Moritz, R.; Karpanen, T.; et al. Biosynthesis of vascular endothelial growth factor-D involves proteolytic processing which generates non-covalent homodimers. J. Biol. Chem. 1999, 274, 32127-32136.

35. Eichmann, A.; Makinen, T.; Alitalo, K. Neural guidance molecules regulate vascular remodeling and vessel navigation. Genes Dev. 2005, 19, 1013-1021. 
36. Karpanen, T.; Heckman, C.A.; Keskitalo, S.; Jeltsch, M.; Ollila, H.; Neufeld, G.; Tamagnone, L.; Alitalo, K. Functional interaction of VEGF-C and VEGF-D with neuropilin receptors. FASEB J. 2006, 20, 1462-1472.

37. Caunt, M.; Mak, J.; Liang, W.C.; Stawicki, S.; Pan, Q.; Tong, R.K.; Kowalski, J.; Ho, C.; Reslan, H.B.; Ross, J.; et al. Blocking neuropilin-2 function inhibits tumor cell metastasis. Cancer Cell 2008, 13, 331-342.

38. Yuan, L.; Moyon, D.; Pardanaud, L.; Breant, C.; Karkkainen, M.J.; Alitalo, K.; Eichmann, A. Abnormal lymphatic vessel development in neuropilin 2 mutant mice. Development 2002, 129, 4797-4806.

39. Hirakawa, S.; Kodama, S.; Kunstfeld, R.; Kajiya, K.; Brown, L.F.; Detmar, M. VEGF-A induces tumor and sentinel lymph node lymphangiogenesis and promotes lymphatic metastasis. J. Exp. Med. 2005, 201, 1089-1099.

40. Halin, C.; Tobler, N.E.; Vigl, B.; Brown, L.F.; Detmar, M. VEGF-A produced by chronically inflamed tissue induces lymphangiogenesis in draining lymph nodes. Blood 2007, 110, 3158-3167.

41. Nagy, J.A.; Vasile, E.; Feng, D.; Sundberg, C.; Brown, L.F.; Detmar, M.J.; Lawitts, J.A.; Benjamin, L.; Tan, X.; Manseau, E.J.; et al. Vascular permeability factor/vascular endothelial growth factor induces lymphangiogenesis as well as angiogenesis. J. Exp. Med. 2002, 196, 1497-1506.

42. Augustin, H.G.; Koh, G.Y.; Thurston, G.; Alitalo, K. Control of vascular morphogenesis and homeostasis through the angiopoietin-Tie system. Nat. Rev. Mol. Cell. Biol. 2009, 10, 165-177.

43. Ward, N.L.; Dumont, D.J. The angiopoietins and Tie2/Tek: Adding to the complexity of cardiovascular development. Semin. Cell Dev. Biol. 2002, 13, 19-27.

44. Yancopoulos, G.D.; Davis, S.; Gale, N.W.; Rudge, J.S.; Wiegand, S.J.; Holash, J. Vascular-specific growth factors and blood vessel formation. Nature 2000, 407, 242-248.

45. Puri, M.C.; Rossant, J.; Alitalo, K.; Bernstein, A.; Partanen, J. The receptor tyrosine kinase TIE is required for integrity and survival of vascular endothelial cells. EMBO J. 1995, 14, 5884-5891.

46. Dumont, D.J.; Gradwohl, G.; Fong, G.H.; Puri, M.C.; Gertsenstein, M.; Auerbach, A.; Breitman, M.L. Dominant-negative and targeted null mutations in the endothelial receptor tyrosine kinase, tek, reveal a critical role in vasculogenesis of the embryo. Genes Dev. 1994, 8, 1897-1909.

47. Sato, T.N.; Tozawa, Y.; Deutsch, U.; Wolburg-Buchholz, K.; Fujiwara, Y.; Gendron-Maguire, M.; Gridley, T.; Wolburg, H.; Risau, W.; Qin, Y. Distinct roles of the receptor tyrosine kinases Tie-1 and Tie-2 in blood vessel formation. Nature 1995, 376, 70-74.

48. Morisada, T.; Oike, Y.; Yamada, Y.; Urano, T.; Akao, M.; Kubota, Y.; Maekawa, H.; Kimura, Y.; Ohmura, M.; Miyamoto, T.; et al. Angiopoietin-1 promotes LYVE-1-positive lymphatic vessel formation. Blood 2005, 105, 4649-4656.

49. Tammela, T.; Saaristo, A.; Lohela, M.; Morisada, T.; Tornberg, J.; Norrmen, C.; Oike, Y.; Pajusola, K.; Thurston, G.; Suda, T.; et al. Angiopoietin-1 promotes lymphatic sprouting and hyperplasia. Blood 2005, 105, 4642-4648. 
50. Kim, K.E.; Cho, C.H.; Kim, H.Z.; Baluk, P.; McDonald, D.M.; Koh, G.Y. In vivo actions of angiopoietins on quiescent and remodeling blood and lymphatic vessels in mouse airways and skin. Arterioscler. Thromb. Vasc. Biol. 2007, 27, 564-570.

51. Davis, S.; Aldrich, T.H.; Jones, P.F.; Acheson, A.; Compton, D.L.; Jain, V.; Ryan, T.E.; Bruno, J.; Radziejewski, C.; Maisonpierre, P.C.; et al. Isolation of angiopoietin-1, a ligand for the TIE2 receptor, by secretion-trap expression cloning. Cell 1996, 87, 1161-1169.

52. Maisonpierre, P.C.; Suri, C.; Jones, P.F.; Bartunkova, S.; Wiegand, S.J.; Radziejewski, C.; Compton, D.; McClain, J.; Aldrich, T.H.; Papadopoulos, N.; et al. Angiopoietin-2, a natural antagonist for Tie2 that disrupts in vivo angiogenesis. Science 1997, 277, 55-60.

53. Valenzuela, D.M.; Griffiths, J.A.; Rojas, J.; Aldrich, T.H.; Jones, P.F.; Zhou, H.; McClain, J.; Copeland, N.G.; Gilbert, D.J.; Jenkins, N.A.; et al. Angiopoietins 3 and 4: Diverging gene counterparts in mice and humans. Proc. Natl. Acad. Sci. USA 1999, 96, 1904-1909.

54. Gale, N.W.; Thurston, G.; Hackett, S.F.; Renard, R.; Wang, Q.; McClain, J.; Martin, C.; Witte, C.; Witte, M.H.; Jackson, D.; et al. Angiopoietin-2 is required for postnatal angiogenesis and lymphatic patterning, and only the latter role is rescued by Angiopoietin-1. Dev. Cell 2002, $3,411-423$.

55. Hong, Y.K.; Harvey, N.; Noh, Y.H.; Schacht, V.; Hirakawa, S.; Detmar, M.; Oliver, G. Prox1 is a master control gene in the program specifying lymphatic endothelial cell fate. Dev. Dyn. 2002, 225, 351-357.

56. Petrova, T.V.; Makinen, T.; Makela, T.P.; Saarela, J.; Virtanen, I.; Ferrell, R.E.; Finegold, D.N.; Kerjaschki, D.; Yla-Herttuala, S.; Alitalo, K. Lymphatic endothelial reprogramming of vascular endothelial cells by the Prox-1 homeobox transcription factor. EMBO J. 2002, 21, 4593-4599.

57. Veikkola, T.; Alitalo, K. Dual role of Ang2 in postnatal angiogenesis and lymphangiogenesis. Dev. Cell 2002, 3, 302-304.

58. Zumsteg, A.; Christofori, G. Myeloid cells and lymphangiogenesis. Cold Spring Harb. Persp. Med. 2012, 2, a006494.

59. Aurora, A.B.; Baluk, P.; Zhang, D.; Sidhu, S.S.; Dolganov, G.M.; Basbaum, C.; McDonald, D.M.; Killeen, N. Immune complex-dependent remodeling of the airway vasculature in response to a chronic bacterial infection. J. Immunol. 2005, 175, 6319-6326.

60. Angeli, V.; Ginhoux, F.; Llodra, J.; Quemeneur, L.; Frenette, P.S.; Skobe, M.; Jessberger, R.; Merad, M.; Randolph, G.J. B cell-driven lymphangiogenesis in inflamed lymph nodes enhances dendritic cell mobilization. Immunity 2006, 24, 203-215.

61. Kang, S.; Lee, S.P.; Kim, K.E.; Kim, H.Z.; Memet, S.; Koh, G.Y. Toll-like receptor 4 in lymphatic endothelial cells contributes to LPS-induced lymphangiogenesis by chemotactic recruitment of macrophages. Blood 2009, 113, 2605-2613.

62. Flister, M.J.; Wilber, A.; Hall, K.L.; Iwata, C.; Miyazono, K.; Nisato, R.E.; Pepper, M.S.; Zawieja, D.C.; Ran, S. Inflammation induces lymphangiogenesis through up-regulation of VEGFR-3 mediated by NF-kappaB and Prox1. Blood 2010, 115, 418-429.

63. Machnik, A.; Neuhofer, W.; Jantsch, J.; Dahlmann, A.; Tammela, T.; Machura, K.; Park, J.K.; Beck, F.X.; Muller, D.N.; Derer, W.; et al. Macrophages regulate salt-dependent volume and blood pressure by a vascular endothelial growth factor-C-dependent buffering mechanism. Nat. Med. 2009, 15, 545-552. 
64. Kubota, Y.; Takubo, K.; Shimizu, T.; Ohno, H.; Kishi, K.; Shibuya, M.; Saya, H.; Suda, T. M-CSF inhibition selectively targets pathological angiogenesis and lymphangiogenesis. J. Exp. Med. 2009, 206, 1089-1102.

65. Schoppmann, S.F.; Birner, P.; Stockl, J.; Kalt, R.; Ullrich, R.; Caucig, C.; Kriehuber, E.; Nagy, K.; Alitalo, K.; Kerjaschki, D. Tumor-associated macrophages express lymphatic endothelial growth factors and are related to peritumoral lymphangiogenesis. Am. J. Pathol. 2002, 161, 947-956.

66. Jeon, B.H.; Jang, C.; Han, J.; Kataru, R.P.; Piao, L.; Jung, K.; Cha, H.J.; Schwendener, R.A.; Jang, K.Y.; Kim, K.S.; et al. Profound but dysfunctional lymphangiogenesis via vascular endothelial growth factor ligands from $\mathrm{CD} 11 \mathrm{~b}+$ macrophages in advanced ovarian cancer. Cancer Res. 2008, 68, 1100-1109.

67. Zhang, B.; Wang, J.; Gao, J.; Guo, Y.; Chen, X.; Wang, B.; Rao, Z.; Chen, Z. Alternatively activated RAW264.7 macrophages enhance tumor lymphangiogenesis in mouse lung adenocarcinoma. J. Cell. Biochem. 2009, 107, 134-143.

68. Yang, H.; Kim, C.; Kim, M.J.; Schwendener, R.A.; Alitalo, K.; Heston, W.; Kim, I.; Kim, W.J.; Koh, G.Y. Soluble vascular endothelial growth factor receptor-3 suppresses lymphangiogenesis and lymphatic metastasis in bladder cancer. Mol. Cancer 2011, 10, 36.

69. Schoppmann, S.F.; Fenzl, A.; Nagy, K.; Unger, S.; Bayer, G.; Geleff, S.; Gnant, M.; Horvat, R.; Jakesz, R.; Birner, P. VEGF-C expressing tumor-associated macrophages in lymph node positive breast cancer: Impact on lymphangiogenesis and survival. Surgery 2006, 139, 839-846.

70. Moussai, D.; Mitsui, H.; Pettersen, J.S.; Pierson, K.C.; Shah, K.R.; Suarez-Farinas, M.; Cardinale, I.R.; Bluth, M.J.; Krueger, J.G.; Carucci, J.A. The human cutaneous squamous cell carcinoma microenvironment is characterized by increased lymphatic density and enhanced expression of macrophage-derived VEGF-C. J. Invest. Dermatol. 2011, 131, 229-236.

71. Algars, A.; Irjala, H.; Vaittinen, S.; Huhtinen, H.; Sundstrom, J.; Salmi, M.; Ristamaki, R.; Jalkanen, S. Type and location of tumor-infiltrating macrophages and lymphatic vessels predict survival of colorectal cancer patients. Int. J. Cancer J. Int. du Cancer 2012, 131, 864-873.

72. Wigle, J.T.; Harvey, N.; Detmar, M.; Lagutina, I.; Grosveld, G.; Gunn, M.D.; Jackson, D.G.; Oliver, G. An essential role for Prox1 in the induction of the lymphatic endothelial cell phenotype. EMBO J. 2002, 21, 1505-1513.

73. Yang, Y.; Garcia-Verdugo, J.M.; Soriano-Navarro, M.; Srinivasan, R.S.; Scallan, J.P.; Singh, M.K.; Epstein, J.A.; Oliver, G. Lymphatic endothelial progenitors bud from the cardinal vein and intersomitic vessels in mammalian embryos. Blood 2012, 120, 2340-2348.

74. Hagerling, R.; Pollmann, C.; Andreas, M.; Schmidt, C.; Nurmi, H.; Adams, R.H.; Alitalo, K.; Andresen, V.; Schulte-Merker, S.; Kiefer, F. A novel multistep mechanism for initial lymphangiogenesis in mouse embryos based on ultramicroscopy. EMBO J. 2013, 32, 629-644.

75. Mouta, C.; Heroult, M. Inflammatory triggers of lymphangiogenesis. Lymphat. Res. Biol. 2003, $1,201-218$.

76. Saharinen, P.; Tammela, T.; Karkkainen, M.J.; Alitalo, K. Lymphatic vasculature: Development, molecular regulation and role in tumor metastasis and inflammation. Trends Immunol. 2004, 25, $387-395$. 
77. Jackson, D.G. New molecular markers for the study of tumour lymphangiogenesis. Anticancer Res. 2001, 21, 4279-4283.

78. Sleeman, J.P.; Krishnan, J.; Kirkin, V.; Baumann, P. Markers for the lymphatic endothelium: In search of the holy grail? Microsc. Res. Tech. 2001, 55, 61-69.

79. Johnson, N.C.; Dillard, M.E.; Baluk, P.; McDonald, D.M.; Harvey, N.L.; Frase, S.L.; Oliver, G. Lymphatic endothelial cell identity is reversible and its maintenance requires Prox1 activity. Genes Dev. 2008, 22, 3282-3291.

80. Francois, M.; Caprini, A.; Hosking, B.; Orsenigo, F.; Wilhelm, D.; Browne, C.; Paavonen, K.; Karnezis, T.; Shayan, R.; Downes, M.; et al. Sox18 induces development of the lymphatic vasculature in mice. Nature 2008, 456, 643-647.

81. Lee, S.; Kang, J.; Yoo, J.; Ganesan, S.K.; Cook, S.C.; Aguilar, B.; Ramu, S.; Lee, J.; Hong, Y.K. Prox1 physically and functionally interacts with COUP-TFII to specify lymphatic endothelial cell fate. Blood 2009, 113, 1856-1859.

82. Srinivasan, R.S.; Geng, X.; Yang, Y.; Wang, Y.; Mukatira, S.; Studer, M.; Porto, M.P.; Lagutin, O.; Oliver, G. The nuclear hormone receptor Coup-TFII is required for the initiation and early maintenance of Prox 1 expression in lymphatic endothelial cells. Genes Dev. 2010, 24, 696-707.

83. Yamazaki, T.; Yoshimatsu, Y.; Morishita, Y.; Miyazono, K.; Watabe, T. COUP-TFII regulates the functions of Prox1 in lymphatic endothelial cells through direct interaction. Genes Cells 2009, 14, 425-434.

84. Halin, C.; Detmar, M. An unexpected connection: Lymph node lymphangiogenesis and dendritic cell migration. Immunity 2006, 24, 129-131.

85. Angeli, V.; Randolph, G.J. Inflammation, lymphatic function, and dendritic cell migration. Lymphat. Res. Biol. 2006, 4, 217-228.

86. Chen, L.; Hamrah, P.; Cursiefen, C.; Zhang, Q.; Pytowski, B.; Streilein, J.W.; Dana, M.R. Vascular endothelial growth factor receptor-3 mediates induction of corneal alloimmunity. Nat. Med. 2004, 10, 813-815.

87. Greco, K.V.; Lara, P.F.; Oliveira-Filho, R.M.; Greco, R.V.; Sudo-Hayashi, L.S. Lymphatic regeneration across an incisional wound: Inhibition by dexamethasone and aspirin, and acceleration by a micronized purified flavonoid fraction. Eur. J. Pharmacol. 2006, 551, 131-142.

88. Paavonen, K.; Puolakkainen, P.; Jussila, L.; Jahkola, T.; Alitalo, K. Vascular endothelial growth factor receptor-3 in lymphangiogenesis in wound healing. Am. J. Pathol. 2000, 156, 1499-1504

89. Kallskog, O.; Kampf, C.; Andersson, A.; Carlsson, P.O.; Hansell, P.; Johansson, M.; Jansson, L. Lymphatic vessels in pancreatic islets implanted under the renal capsule of rats. Am. J. Transplant. 2006, 6, 680-686.

90. Kerjaschki, D.; Huttary, N.; Raab, I.; Regele, H.; Bojarski-Nagy, K.; Bartel, G.; Krober, S.M.; Greinix, H.; Rosenmaier, A.; Karlhofer, F.; et al. Lymphatic endothelial progenitor cells contribute to de novo lymphangiogenesis in human renal transplants. Nat. Med. 2006, 12, 230-234.

91. Ling, S.; Qi, C.; Li, W.; Xu, J.; Kuang, W. The expression of vascular endothelial growth factor C in transplanted corneas. Curr. Eye Res. 2009, 34, 553-561.

92. Alitalo, A.; Detmar, M. Interaction of tumor cells and lymphatic vessels in cancer progression. Oncogene 2012, 31, 4499-4508. 
93. Shields, J.D. Lymphatics: At the interface of immunity, tolerance, and tumor metastasis. Microcirculation 2011, 18, 517-531.

94. Zgraggen, S.; Ochsenbein, A.M.; Detmar, M. An important role of blood and lymphatic vessels in inflammation and allergy. J. Allergy (Cairo) 2013, 2013, 672381.

95. Sundar, S.S.; Ganesan, T.S. Role of lymphangiogenesis in cancer. J. Clin. Oncol. Off. J. Am. Soc. Clin. Oncol. 2007, 25, 4298-4307.

96. El-Chemaly, S.; Levine, S.J.; Moss, J. Lymphatics in lung disease. Ann. NY Acad. Sci. 2008, $1131,195-202$.

97. Oliver, G.; Alitalo, K. The lymphatic vasculature: Recent progress and paradigms. Annu. Rev. Cell Dev. Biol. 2005, 21, 457-483.

98. Baluk, P.; Yao, L.C.; Feng, J.; Romano, T.; Jung, S.S.; Schreiter, J.L.; Yan, L.; Shealy, D.J.; McDonald, D.M. TNF-alpha drives remodeling of blood vessels and lymphatics in sustained airway inflammation in mice. J. Clin. Invest. 2009, 119, 2954-2964.

99. Hoshida, T.; Isaka, N.; Hagendoorn, J.; di Tomaso, E.; Chen, Y.L.; Pytowski, B.; Fukumura, D.; Padera, T.P.; Jain, R.K. Imaging steps of lymphatic metastasis reveals that vascular endothelial growth factor-C increases metastasis by increasing delivery of cancer cells to lymph nodes: Therapeutic implications. Cancer Res. 2006, 66, 8065-8075.

100. Cursiefen, C.; Chen, L.; Borges, L.P.; Jackson, D.; Cao, J.; Radziejewski, C.; D’Amore, P.A.; Dana, M.R.; Wiegand, S.J.; Streilein, J.W. VEGF-A stimulates lymphangiogenesis and hemangiogenesis in inflammatory neovascularization via macrophage recruitment. J. Clin. Invest. 2004, 113, 1040-1050.

101. Ristimaki, A.; Narko, K.; Enholm, B.; Joukov, V.; Alitalo, K. Proinflammatory cytokines regulate expression of the lymphatic endothelial mitogen vascular endothelial growth factor-C. J. Biol. Chem. 1998, 273, 8413-8418.

102. Jeltsch, M.; Kaipainen, A.; Joukov, V.; Meng, X.; Lakso, M.; Rauvala, H.; Swartz, M.; Fukumura, D.; Jain, R.K.; Alitalo, K. Hyperplasia of lymphatic vessels in VEGF-C transgenic mice. Science 1997, 276, 1423-1425.

103. Guo, R.; Zhou, Q.; Proulx, S.T.; Wood, R.; Ji, R.C.; Ritchlin, C.T.; Pytowski, B.; Zhu, Z.; Wang, Y.J.; Schwarz, E.M.; et al. Inhibition of lymphangiogenesis and lymphatic drainage via vascular endothelial growth factor receptor 3 blockade increases the severity of inflammation in a mouse model of chronic inflammatory arthritis. Arthritis Rheumat. 2009, 60, 2666-2676.

104. Hamrah, P.; Chen, L.; Zhang, Q.; Dana, M.R. Novel expression of vascular endothelial growth factor receptor (VEGFR)-3 and VEGF-C on corneal dendritic cells. Am. J. Pathol. 2003, 163, $57-68$.

105. Martinez-Corral, I.; Makinen, T. Regulation of lymphatic vascular morphogenesis: Implications for pathological (tumor) lymphangiogenesis. Exp. Cell. Res. 2013, 319, 1618-1625.

106. Nagahashi, M.; Ramachandran, S.; Rashid, O.M.; Takabe, K. Lymphangiogenesis: A new player in cancer progression. World J. Gastroenterol. WJG 2010, 16, 4003-4012.

107. Tammela, T.; He, Y.; Lyytikka, J.; Jeltsch, M.; Markkanen, J.; Pajusola, K.; Yla-Herttuala, S.; Alitalo, K. Distinct architecture of lymphatic vessels induced by chimeric vascular endothelial growth factor-C/vascular endothelial growth factor heparin-binding domain fusion proteins. Circ. Res. 2007, 100, 1468-1475. 
108. He, Y.; Rajantie, I.; Pajusola, K.; Jeltsch, M.; Holopainen, T.; Yla-Herttuala, S.; Harding, T.; Jooss, K.; Takahashi, T.; Alitalo, K. Vascular endothelial cell growth factor receptor 3-mediated activation of lymphatic endothelium is crucial for tumor cell entry and spread via lymphatic vessels. Cancer Res. 2005, 65, 4739-4746.

109. Lin, F.J.; Chen, X.; Qin, J.; Hong, Y.K.; Tsai, M.J.; Tsai, S.Y. Direct transcriptional regulation of neuropilin-2 by COUP-TFII modulates multiple steps in murine lymphatic vessel development. J. Clin. Invest. 2010, 120, 1694-1707.

110. Duong, T.; Proulx, S.T.; Luciani, P.; Leroux, J.C.; Detmar, M.; Koopman, P.; Francois, M. Genetic ablation of SOX18 function suppresses tumor lymphangiogenesis and metastasis of melanoma in mice. Cancer Res. 2012, 72, 3105-3114.

111. Stacker, S.A.; Caesar, C.; Baldwin, M.E.; Thornton, G.E.; Williams, R.A.; Prevo, R.; Jackson, D.G.; Nishikawa, S.; Kubo, H.; Achen, M.G. VEGF-D promotes the metastatic spread of tumor cells via the lymphatics. Nat. Med. 2001, 7, 186-191.

112. Mandriota, S.J.; Jussila, L.; Jeltsch, M.; Compagni, A.; Baetens, D.; Prevo, R.; Banerji, S.; Huarte, J.; Montesano, R.; Jackson, D.G.; et al. Vascular endothelial growth factor-C-mediated lymphangiogenesis promotes tumour metastasis. EMBO J. 2001, 20, 672-682.

113. Karpanen, T.; Egeblad, M.; Karkkainen, M.J.; Kubo, H.; Yla-Herttuala, S.; Jaattela, M.; Alitalo, K. Vascular endothelial growth factor C promotes tumor lymphangiogenesis and intralymphatic tumor growth. Cancer Res. 2001, 61, 1786-1790.

114. Skobe, M.; Hawighorst, T.; Jackson, D.G.; Prevo, R.; Janes, L.; Velasco, P.; Riccardi, L.; Alitalo, K.; Claffey, K.; Detmar, M. Induction of tumor lymphangiogenesis by VEGF-C promotes breast cancer metastasis. Nat. Med. 2001, 7, 192-198.

115. He, Y.; Kozaki, K.; Karpanen, T.; Koshikawa, K.; Yla-Herttuala, S.; Takahashi, T.; Alitalo, K. Suppression of tumor lymphangiogenesis and lymph node metastasis by blocking vascular endothelial growth factor receptor 3 signaling. J. Natl. Cancer Instit. 2002, 94, 819-825.

116. Krishnan, J.; Kirkin, V.; Steffen, A.; Hegen, M.; Weih, D.; Tomarev, S.; Wilting, J.; Sleeman, J.P. Differential in vivo and in vitro expression of vascular endothelial growth factor (VEGF)-C and VEGF-D in tumors and its relationship to lymphatic metastasis in immunocompetent rats. Cancer Res. 2003, 63, 713-722.

117. Kopfstein, L.; Veikkola, T.; Djonov, V.G.; Baeriswyl, V.; Schomber, T.; Strittmatter, K.; Stacker, S.A.; Achen, M.G.; Alitalo, K.; Christofori, G. Distinct roles of vascular endothelial growth factor-D in lymphangiogenesis and metastasis. Am. J. Pathol. 2007, 170, 1348-1361.

118. Hirakawa, S.; Brown, L.F.; Kodama, S.; Paavonen, K.; Alitalo, K.; Detmar, M. VEGF-C-induced lymphangiogenesis in sentinel lymph nodes promotes tumor metastasis to distant sites. Blood 2007, 109, 1010-1017.

119. Christiansen, A.; Detmar, M. Lymphangiogenesis and cancer. Genes Cancer 2011, 2, 1146-1158.

120. Cao, R.; Ji, H.; Feng, N.; Zhang, Y.; Yang, X.; Andersson, P.; Sun, Y.; Tritsaris, K.; Hansen, A.J.; Dissing, S.; et al. Collaborative interplay between FGF-2 and VEGF-C promotes lymphangiogenesis and metastasis. Proc. Natl. Acad. Sci. USA 2012, 109, 15894-15899.

121. Larrieu-Lahargue, F.; Welm, A.L.; Bouchecareilh, M.; Alitalo, K.; Li, D.Y.; Bikfalvi, A.; Auguste, P. Blocking fibroblast growth factor receptor signaling inhibits tumor growth, lymphangiogenesis, and metastasis. PLoS One 2012, 7, e39540. 
122. O’Farrell, A.M.; Abrams, T.J.; Yuen, H.A.; Ngai, T.J.; Louie, S.G.; Yee, K.W.; Wong, L.M.; Hong, W.; Lee, L.B.; Town, A.; et al. SU11248 is a novel FLT3 tyrosine kinase inhibitor with potent activity in vitro and in vivo. Blood 2003, 101, 3597-3605.

123. Nasarre, P.; Thomas, M.; Kruse, K.; Helfrich, I.; Wolter, V.; Deppermann, C.; Schadendorf, D.; Thurston, G.; Fiedler, U.; Augustin, H.G. Host-derived angiopoietin-2 affects early stages of tumor development and vessel maturation but is dispensable for later stages of tumor growth. Cancer Res. 2009, 69, 1324-1333.

124. Lin, P.; Polverini, P.; Dewhirst, M.; Shan, S.; Rao, P.S.; Peters, K. Inhibition of tumor angiogenesis using a soluble receptor establishes a role for Tie2 in pathologic vascular growth. J. Clin. Invest. 1997, 100, 2072-2078.

125. Lin, P.; Buxton, J.A.; Acheson, A.; Radziejewski, C.; Maisonpierre, P.C.; Yancopoulos, G.D.; Channon, K.M.; Hale, L.P.; Dewhirst, M.W.; George, S.E.; et al. Antiangiogenic gene therapy targeting the endothelium-specific receptor tyrosine kinase Tie2. Proc. Natl. Acad. Sci. USA 1998, 95, 8829-8834.

126. He, Y.; Rajantie, I.; Ilmonen, M.; Makinen, T.; Karkkainen, M.J.; Haiko, P.; Salven, P.; Alitalo, K. Preexisting lymphatic endothelium but not endothelial progenitor cells are essential for tumor lymphangiogenesis and lymphatic metastasis. Cancer Res. 2004, 64, 3737-3740.

127. Gordon, E.J.; Rao, S.; Pollard, J.W.; Nutt, S.L.; Lang, R.A.; Harvey, N.L. Macrophages define dermal lymphatic vessel calibre during development by regulating lymphatic endothelial cell proliferation. Development 2010, 137, 3899-3910.

128. Maceyka, M.; Harikumar, K.B.; Milstien, S.; Spiegel, S. Sphingosine-1-phosphate signaling and its role in disease. Trends Cell Biol. 2012, 22, 50-60.

129. Takabe, K.; Paugh, S.W.; Milstien, S.; Spiegel, S. "Inside-out" signaling of sphingosine-1phosphate: Therapeutic targets. Pharmacol. Rev. 2008, 60, 181-195.

130. Le Stunff, H.; Milstien, S.; Spiegel, S. Generation and metabolism of bioactive sphingosine-1phosphate. J. Cell. Biochem. 2004, 92, 882-899.

131. Ghosh, T.K.; Bian, J.; Gill, D.L. Intracellular calcium release mediated by sphingosine derivatives generated in cells. Science 1990, 248, 1653-1656.

132. Ghosh, T.K.; Bian, J.; Gill, D.L. Sphingosine 1-phosphate generated in the endoplasmic reticulum membrane activates release of stored calcium. J. Biol. Chem. 1994, 269, 22628-22635.

133. Mattie, M.; Brooker, G.; Spiegel, S. Sphingosine-1-phosphate, a putative second messenger, mobilizes calcium from internal stores via an inositol trisphosphate-independent pathway. J. Biol. Chem. 1994, 269, 3181-3188.

134. Alvarez, S.E.; Harikumar, K.B.; Hait, N.C.; Allegood, J.; Strub, G.M.; Kim, E.Y.; Maceyka, M.; Jiang, H.; Luo, C.; Kordula, T.; et al. Sphingosine-1-phosphate is a missing cofactor for the E3 ubiquitin ligase TRAF2. Nature 2010, 465, 1084-1088.

135. Hait, N.C.; Allegood, J.; Maceyka, M.; Strub, G.M.; Harikumar, K.B.; Singh, S.K.; Luo, C.; Marmorstein, R.; Kordula, T.; Milstien, S.; et al. Regulation of histone acetylation in the nucleus by sphingosine-1-phosphate. Science 2009, 325, 1254-1257.

136. Sato, K.; Malchinkhuu, E.; Horiuchi, Y.; Mogi, C.; Tomura, H.; Tosaka, M.; Yoshimoto, Y.; Kuwabara, A.; Okajima, F. Critical role of ABCA1 transporter in sphingosine 1-phosphate release from astrocytes. J. Neurochem. 2007, 103, 2610-2619. 
137. Mitra, P.; Oskeritzian, C.A.; Payne, S.G.; Beaven, M.A.; Milstien, S.; Spiegel, S. Role of ABCC1 in export of sphingosine-1-phosphate from mast cells. Proc. Natl. Acad. Sci. USA 2006, 103, 16394-16399.

138. Takabe, K.; Kim, R.H.; Allegood, J.C.; Mitra, P.; Ramachandran, S.; Nagahashi, M.; Harikumar, K.B.; Hait, N.C.; Milstien, S.; Spiegel, S. Estradiol induces export of sphingosine 1-phosphate from breast cancer cells via ABCC1 and ABCG2. J. Biol. Chem. 2010, 285, 10477-10486

139. Kawahara, A.; Nishi, T.; Hisano, Y.; Fukui, H.; Yamaguchi, A.; Mochizuki, N. The sphingolipid transporter spns2 functions in migration of zebrafish myocardial precursors. Science 2009, 323, $524-527$.

140. Nagahashi, M.; Kim, E.Y.; Yamada, A.; Ramachandran, S.; Allegood, J.C.; Hait, N.C.; Maceyka, M.; Milstien, S.; Takabe, K.; Spiegel, S. Spns2, a transporter of phosphorylated sphingoid bases, regulates their blood and lymph levels, and the lymphatic network. FASEB J. 2013, 27, 1001-1011.

141. Pham, T.H.; Baluk, P.; Xu, Y.; Grigorova, I.; Bankovich, A.J.; Pappu, R.; Coughlin, S.R.; McDonald, D.M.; Schwab, S.R.; Cyster, J.G. Lymphatic endothelial cell sphingosine kinase activity is required for lymphocyte egress and lymphatic patterning. J. Exp. Med. 2010, 207, 17-27.

142. Kim, R.H.; Takabe, K.; Milstien, S.; Spiegel, S. Export and functions of sphingosine-1phosphate. Biochim. Biophys. Acta 2009, 1791, 692-696.

143. Mendoza, A.; Breart, B.; Ramos-Perez, W.D.; Pitt, L.A.; Gobert, M.; Sunkara, M.; Lafaille, J.J.; Morris, A.J.; Schwab, S.R. The transporter Spns2 is required for secretion of lymph but not plasma sphingosine-1-phosphate. Cell. Rep. 2012, 2, 1104-1110.

144. Hisano, Y.; Kobayashi, N.; Kawahara, A.; Yamaguchi, A.; Nishi, T. The sphingosine 1-phosphate transporter, SPNS2, functions as a transporter of the phosphorylated form of the immunomodulating agent FTY720. J. Biol. Chem. 2011, 286, 1758-1766.

145. Fukuhara, S.; Simmons, S.; Kawamura, S.; Inoue, A.; Orba, Y.; Tokudome, T.; Sunden, Y.; Arai, Y.; Moriwaki, K.; Ishida, J.; et al. The sphingosine-1-phosphate transporter Spns2 expressed on endothelial cells regulates lymphocyte trafficking in mice. J. Clin. Invest. 2012 , $122,1416-1426$.

146. Nijnik, A.; Clare, S.; Hale, C.; Chen, J.; Raisen, C.; Mottram, L.; Lucas, M.; Estabel, J.; Ryder, E.; Adissu, H.; et al. The role of sphingosine-1-phosphate transporter Spns2 in immune system function. J. Immunol. 2012, 189, 102-111.

147. Hisano, Y.; Kobayashi, N.; Yamaguchi, A.; Nishi, T. Mouse SPNS2 functions as a sphingosine-1-phosphate transporter in vascular endothelial cells. PLoS One 2012, 7, e38941.

148. Yamada, A.; Ishikawa, T.; Ota, I.; Kimura, M.; Shimizu, D.; Tanabe, M.; Chishima, T.; Sasaki, T.; Ichikawa, Y.; Morita, S.; et al. High expression of ATP-binding cassette transporter ABCC11 in breast tumors is associated with aggressive subtypes and low disease-free survival. Breast Cancer Res. Treat. 2013, 137, 773-782.

149. Rivera, J.; Proia, R.L.; Olivera, A. The alliance of sphingosine-1-phosphate and its receptors in immunity. Nat. Rev. Immunol. 2008, 8, 753-763. 
150. Spiegel, S.; Milstien, S. The outs and the ins of sphingosine-1-phosphate in immunity. Nat. Rev. Immunol. 2011, 11, 403-415.

151. Pyne, N.J.; Pyne, S. Sphingosine 1-phosphate and cancer. Nat. Rev. Cancer 2010, 10, 489-503.

152. Chi, H. Sphingosine-1-phosphate and immune regulation: Trafficking and beyond. Trends Pharmacol. Sci. 2011, 32, 16-24.

153. Pham, T.H.; Okada, T.; Matloubian, M.; Lo, C.G.; Cyster, J.G. S1P1 receptor signaling overrides retention mediated by $\mathrm{G}$ alpha $\mathrm{i}$-coupled receptors to promote $\mathrm{T}$ cell egress. Immunity 2008, 28, $122-133$.

154. Cyster, J.G. B cell follicles and antigen encounters of the third kind. Nat. Immunol. 2010, 11, 989-996.

155. Jenne, C.N.; Enders, A.; Rivera, R.; Watson, S.R.; Bankovich, A.J.; Pereira, J.P.; Xu, Y.; Roots, C.M.; Beilke, J.N.; Banerjee, A.; et al. T-bet-dependent S1P5 expression in NK cells promotes egress from lymph nodes and bone marrow. J. Exp. Med. 2009, 206, 2469-2481.

156. Allende, M.L.; Bektas, M.; Lee, B.G.; Bonifacino, E.; Kang, J.; Tuymetova, G.; Chen, W.; Saba, J.D.; Proia, R.L. Sphingosine-1-phosphate lyase deficiency produces a pro-inflammatory response while impairing neutrophil trafficking. J. Biol. Chem. 2011, 286, 7348-7358.

157. Liu, Y.; Wada, R.; Yamashita, T.; Mi, Y.; Deng, C.X.; Hobson, J.P.; Rosenfeldt, H.M.; Nava, V.E.; Chae, S.S.; Lee, M.J.; et al. Edg-1, the G protein-coupled receptor for sphingosine1-phosphate, is essential for vascular maturation. J. Clin. Invest. 2000, 106, 951-961.

158. Kono, M.; Mi, Y.; Liu, Y.; Sasaki, T.; Allende, M.L.; Wu, Y.P.; Yamashita, T.; Proia, R.L. The sphingosine-1-phosphate receptors S1P1, S1P2, and S1P3 function coordinately during embryonic angiogenesis. J. Biol. Chem. 2004, 279, 29367-29373.

159. Brinkmann, V.; Billich, A.; Baumruker, T.; Heining, P.; Schmouder, R.; Francis, G.; Aradhye, S.; Burtin, P. Fingolimod (FTY720): Discovery and development of an oral drug to treat multiple sclerosis. Nat. Rev. Drug Discov. 2010, 9, 883-897.

160. Allende, M.L.; Sasaki, T.; Kawai, H.; Olivera, A.; Mi, Y.; van Echten-Deckert, G.; Hajdu, R.; Rosenbach, M.; Keohane, C.A.; Mandala, S.; et al. Mice deficient in sphingosine kinase 1 are rendered lymphopenic by FTY720. J. Biol. Chem. 2004, 279, 52487-52492.

161. Kharel, Y.; Lee, S.; Snyder, A.H.; Sheasley-O'neill, S.L.; Morris, M.A.; Setiady, Y.; Zhu, R.; Zigler, M.A.; Burcin, T.L.; Ley, K.; et al. Sphingosine kinase 2 is required for modulation of lymphocyte traffic by FTY720. J. Biol. Chem. 2005, 280, 36865-36872.

162. Zemann, B.; Kinzel, B.; Muller, M.; Reuschel, R.; Mechtcheriakova, D.; Urtz, N.; Bornancin, F.; Baumruker, T.; Billich, A. Sphingosine kinase type 2 is essential for lymphopenia induced by the immunomodulatory drug FTY720. Blood 2006, 107, 1454-1458.

163. Matloubian, M.; Lo, C.G.; Cinamon, G.; Lesneski, M.J.; Xu, Y.; Brinkmann, V.; Allende, M.L.; Proia, R.L.; Cyster, J.G. Lymphocyte egress from thymus and peripheral lymphoid organs is dependent on S1P receptor 1. Nature 2004, 427, 355-360.

164. Graler, M.H.; Goetzl, E.J. The immunosuppressant FTY720 down-regulates sphingosine 1phosphate G-protein-coupled receptors. FASEB J. 2004, 18, 551-553.

165. Cyster, J.G. Chemokines, sphingosine-1-phosphate, and cell migration in secondary lymphoid organs. Annu. Rev. Immunol. 2005, 23, 127-159. 
166. Deguchi, Y.; Andoh, A.; Yagi, Y.; Bamba, S.; Inatomi, O.; Tsujikawa, T.; Fujiyama, Y. The S1P receptor modulator FTY720 prevents the development of experimental colitis in mice. Oncol. Rep. 2006, 16, 699-703.

167. Wang, F.; Tan, W.; Guo, D.; He, S. Reduction of CD4 positive T cells and improvement of pathological changes of collagen-induced arthritis by FTY720. Eur. J. Pharmacol. 2007, 573, 230-240.

168. Idzko, M.; Hammad, H.; van Nimwegen, M.; Kool, M.; Muller, T.; Soullie, T.; Willart, M.A.; Hijdra, D.; Hoogsteden, H.C.; Lambrecht, B.N. Local application of FTY720 to the lung abrogates experimental asthma by altering dendritic cell function. J. Clin. Invest. 2006, 116, 2935-2944.

169. Puneet, P.; Yap, C.T.; Wong, L.; Lam, Y.; Koh, D.R.; Moochhala, S.; Pfeilschifter, J.; Huwiler, A.; Melendez, A.J. SphK1 regulates proinflammatory responses associated with endotoxin and polymicrobial sepsis. Science 2010, 328, 1290-1294.

170. Xia, P.; Gamble, J.R.; Rye, K.A.; Wang, L.; Hii, C.S.; Cockerill, P.; Khew-Goodall, Y.; Bert, A.G.; Barter, P.J.; Vadas, M.A. Tumor necrosis factor-alpha induces adhesion molecule expression through the sphingosine kinase pathway. Proc. Natl. Acad. Sci. USA 1998, 95, 14196-14201.

171. Pettus, B.J.; Bielawski, J.; Porcelli, A.M.; Reames, D.L.; Johnson, K.R.; Morrow, J.; Chalfant, C.E.; Obeid, L.M.; Hannun, Y.A. The sphingosine kinase 1/sphingosine-1-phosphate pathway mediates COX-2 induction and PGE2 production in response to TNF-alpha. FASEB J. 2003, 17, 1411-1421.

172. Billich, A.; Bornancin, F.; Mechtcheriakova, D.; Natt, F.; Huesken, D.; Baumruker, T. Basal and induced sphingosine kinase 1 activity in A549 carcinoma cells: Function in cell survival and IL-1beta and TNF-alpha induced production of inflammatory mediators. Cell. Signal. 2005, 17, 1203-1217.

173. Alvarez, S.E.; Milstien, S.; Spiegel, S. Autocrine and paracrine roles of sphingosine-1-phosphate. Trends Endocrinol. Metab. TEM 2007, 18, 300-307.

174. Shida, D.; Takabe, K.; Kapitonov, D.; Milstien, S.; Spiegel, S. Targeting SphK1 as a new strategy against cancer. Curr. Drug Targets 2008, 9, 662-673.

175. Liu, H.; Toman, R.E.; Goparaju, S.K.; Maceyka, M.; Nava, V.E.; Sankala, H.; Payne, S.G.; Bektas, M.; Ishii, I.; Chun, J.; et al. Sphingosine kinase type 2 is a putative BH3-only protein that induces apoptosis. J. Biol. Chem. 2003, 278, 40330-40336.

176. Maceyka, M.; Sankala, H.; Hait, N.C.; Le Stunff, H.; Liu, H.; Toman, R.; Collier, C.; Zhang, M.; Satin, L.S.; Merrill, A.H., Jr.; et al. SphK1 and SphK2, sphingosine kinase isoenzymes with opposing functions in sphingolipid metabolism. J. Biol. Chem. 2005, 280, 37118-37129.

177. Paugh, B.S.; Paugh, S.W.; Bryan, L.; Kapitonov, D.; Wilczynska, K.M.; Gopalan, S.M.; Rokita, H.; Milstien, S.; Spiegel, S.; Kordula, T. EGF regulates plasminogen activator inhibitor-1 (PAI-1) by a pathway involving c-Src, PKCdelta, and sphingosine kinase 1 in glioblastoma cells. FASEB J. 2008, 22, 455-465.

178. Xia, P.; Gamble, J.R.; Wang, L.; Pitson, S.M.; Moretti, P.A.; Wattenberg, B.W.; D’Andrea, R.J.; Vadas, M.A. An oncogenic role of sphingosine kinase. Curr. Biol. CB 2000, 10, 1527-1530. 
179. Shu, X.; Wu, W.; Mosteller, R.D.; Broek, D. Sphingosine kinase mediates vascular endothelial growth factor-induced activation of ras and mitogen-activated protein kinases. Mol. Cell. Biol. 2002, 22, 7758-7768.

180. French, K.J.; Schrecengost, R.S.; Lee, B.D.; Zhuang, Y.; Smith, S.N.; Eberly, J.L.; Yun, J.K.; Smith, C.D. Discovery and evaluation of inhibitors of human sphingosine kinase. Cancer Res. 2003, 63, 5962-5969.

181. Johnson, K.R.; Johnson, K.Y.; Crellin, H.G.; Ogretmen, B.; Boylan, A.M.; Harley, R.A.; Obeid, L.M. Immunohistochemical distribution of sphingosine kinase 1 in normal and tumor lung tissue. J. Histochem. Cytochem. 2005, 53, 1159-1166.

182. Kohno, M.; Momoi, M.; Oo, M.L.; Paik, J.H.; Lee, Y.M.; Venkataraman, K.; Ai, Y.; Ristimaki, A.P.; Fyrst, H.; Sano, H.; et al. Intracellular role for sphingosine kinase 1 in intestinal adenoma cell proliferation. Mol. Cell. Biol. 2006, 26, 7211-7223.

183. Paugh, S.W.; Paugh, B.S.; Rahmani, M.; Kapitonov, D.; Almenara, J.A.; Kordula, T.; Milstien, S.; Adams, J.K.; Zipkin, R.E.; Grant, S.; et al. A selective sphingosine kinase 1 inhibitor integrates multiple molecular therapeutic targets in human leukemia. Blood 2008, 112, 1382-1391.

184. Kapitonov, D.; Allegood, J.C.; Mitchell, C.; Hait, N.C.; Almenara, J.A.; Adams, J.K.; Zipkin, R.E.; Dent, P.; Kordula, T.; Milstien, S.; et al. Targeting sphingosine kinase 1 inhibits Akt signaling, induces apoptosis, and suppresses growth of human glioblastoma cells and xenografts. Cancer Res. 2009, 69, 6915-6923.

185. French, K.J.; Zhuang, Y.; Maines, L.W.; Gao, P.; Wang, W.; Beljanski, V.; Upson, J.J.; Green, C.L.; Keller, S.N.; Smith, C.D. Pharmacology and antitumor activity of ABC294640, a selective inhibitor of sphingosine kinase-2. J. Pharmacol. Exp. Ther. 2010, 333, 129-139.

186. Salas, A.; Ponnusamy, S.; Senkal, C.E.; Meyers-Needham, M.; Selvam, S.P.; Saddoughi, S.A.; Apohan, E.; Sentelle, R.D.; Smith, C.; Gault, C.R.; et al. Sphingosine kinase-1 and sphingosine 1-phosphate receptor 2 mediate Bcr-Abl1 stability and drug resistance by modulation of protein phosphatase 2A. Blood 2011, 117, 5941-5952.

187. Kim, E.S.; Kim, J.S.; Kim, S.G.; Hwang, S.; Lee, C.H.; Moon, A. Sphingosine 1-phosphate regulates matrix metalloproteinase-9 expression and breast cell invasion through S1P3-Galphaq coupling. J. Cell. Sci. 2011, 124, 2220-2230.

188. Anelli, V.; Gault, C.R.; Snider, A.J.; Obeid, L.M. Role of sphingosine kinase-1 in paracrine/ transcellular angiogenesis and lymphangiogenesis in vitro. FASEB J. 2010, 24, 2727-2738.

189. Lee, H.; Deng, J.; Kujawski, M.; Yang, C.; Liu, Y.; Herrmann, A.; Kortylewski, M.; Horne, D.; Somlo, G.; Forman, S.; et al. STAT3-induced S1PR1 expression is crucial for persistent STAT3 activation in tumors. Nat. Med. 2010, 16, 1421-1428.

190. Liang, J.; Nagahashi, M.; Kim, E.Y.; Harikumar, K.B.; Yamada, A.; Huang, W.C.; Hait, N.C.; Allegood, J.C.; Price, M.M.; Avni, D.; et al. Sphingosine-1-phosphate links persistent STAT3 activation, chronic intestinal inflammation, and development of colitis-associated cancer. Cancer Cell 2013, 23, 107-120.

191. Visentin, B.; Vekich, J.A.; Sibbald, B.J.; Cavalli, A.L.; Moreno, K.M.; Matteo, R.G.; Garland, W.A.; Lu, Y.; Yu, S.; Hall, H.S.; et al. Validation of an anti-sphingosine-1-phosphate antibody as a potential therapeutic in reducing growth, invasion, and angiogenesis in multiple tumor lineages. Cancer Cell 2006, 9, 225-238. 
192. LaMontagne, K.; Littlewood-Evans, A.; Schnell, C.; O’Reilly, T.; Wyder, L.; Sanchez, T.; Probst, B.; Butler, J.; Wood, A.; Liau, G.; et al. Antagonism of sphingosine-1-phosphate receptors by FTY720 inhibits angiogenesis and tumor vascularization. Cancer Res. 2006, 66, 221-231.

193. Takabe, K.; Yamada, A.; Rashid, O.; Adams, B.; Huang, W.; Aoyagi, T.; Nagahashi, M. Twofer anti-vascular therapy targeting sphingosine-1-phosphate for breast cancer. Gland Surg. 2012, 1, 80-83.

194. Aoyagi, T.; Nagahashi, M.; Yamada, A.; Takabe, K. The role of sphingosine-1-phosphate in breast cancer tumor-induced lymphangiogenesis. Lymphat. Res. Biol. 2012, 10, 97-106.

195. Yoon, C.M.; Hong, B.S.; Moon, H.G.; Lim, S.; Suh, P.G.; Kim, Y.K.; Chae, C.B.; Gho, Y.S. Sphingosine-1-phosphate promotes lymphangiogenesis by stimulating S1P1/Gi/PLC/Ca2+ signaling pathways. Blood 2008, 112, 1129-1138.

196. Lee, M.J.; Thangada, S.; Claffey, K.P.; Ancellin, N.; Liu, C.H.; Kluk, M.; Volpi, M.; Sha'afi, R.I.; Hla, T. Vascular endothelial cell adherens junction assembly and morphogenesis induced by sphingosine-1-phosphate. Cell 1999, 99, 301-312.

197. Lee, O.H.; Kim, Y.M.; Lee, Y.M.; Moon, E.J.; Lee, D.J.; Kim, J.H.; Kim, K.W.; Kwon, Y.G. Sphingosine 1-phosphate induces angiogenesis: Its angiogenic action and signaling mechanism in human umbilical vein endothelial cells. Biochem. Biophys. Res. Commun. 1999, 264, 743-750.

198. Jang, C.; Koh, Y.J.; Lim, N.K.; Kang, H.J.; Kim, D.H.; Park, S.K.; Lee, G.M.; Jeon, C.J.; Koh, G.Y. Angiopoietin-2 exocytosis is stimulated by sphingosine-1-phosphate in human blood and lymphatic endothelial cells. Arterioscler. Thromb. Vasc. Biol. 2009, 29, 401-407.

199. Nagahashi, M.; Ramachandran, S.; Kim, E.Y.; Allegood, J.C.; Rashid, O.M.; Yamada, A.; Zhao, R.; Milstien, S.; Zhou, H.; Spiegel, S.; et al. Sphingosine-1-phosphate produced by sphingosine kinase 1 promotes breast cancer progression by stimulating angiogenesis and lymphangiogenesis. Cancer Res. 2012, 72, 726-735.

200. Mumprecht, V.; Honer, M.; Vigl, B.; Proulx, S.T.; Trachsel, E.; Kaspar, M.; Banziger-Tobler, N.E.; Schibli, R.; Neri, D.; Detmar, M. In vivo imaging of inflammation- and tumor-induced lymph node lymphangiogenesis by immuno-positron emission tomography. Cancer Res. 2010, 70, 8842-8851.

201. Edge, S.B.; Compton, C.C. The American Joint Committee on Cancer: The 7th edition of the AJCC cancer staging manual and the future of TNM. Ann. Surg. Oncol. 2010, 17, 1471-1474.

202. Mizugishi, K.; Yamashita, T.; Olivera, A.; Miller, G.F.; Spiegel, S.; Proia, R.L. Essential role for sphingosine kinases in neural and vascular development. Mol. Cell. Biol.2005, 25, 11113-11121.

203. Zemann, B.; Urtz, N.; Reuschel, R.; Mechtcheriakova, D.; Bornancin, F.; Badegruber, R.; Baumruker, T.; Billich, A. Normal neutrophil functions in sphingosine kinase type 1 and 2 knockout mice. Immunol. Lett. 2007, 109, 56-63.

204. Jung, B.; Obinata, H.; Galvani, S.; Mendelson, K.; Ding, B.S.; Skoura, A.; Kinzel, B.; Brinkmann, V.; Rafii, S.; Evans, T.; et al. Flow-regulated endothelial S1P receptor-1 signaling sustains vascular development. Dev. Cell 2012, 23, 600-610.

205. Gaengel, K.; Niaudet, C.; Hagikura, K.; Lavina, B.; Muhl, L.; Hofmann, J.J.; Ebarasi, L.; Nystrom, S.; Rymo, S.; Chen, L.L.; et al. The sphingosine-1-phosphate receptor S1PR1 restricts sprouting angiogenesis by regulating the interplay between VE-cadherin and VEGFR2. Dev. Cell 2012, 23, 587-599. 
206. Ben Shoham, A.; Malkinson, G.; Krief, S.; Shwartz, Y.; Ely, Y.; Ferrara, N.; Yaniv, K.; Zelzer, E. S1P1 inhibits sprouting angiogenesis during vascular development. Development 2012, 139, 3859-3869.

207. Mendelson, K.; Zygmunt, T.; Torres-Vazquez, J.; Evans, T.; Hla, T. Sphingosine 1-phosphate receptor signaling regulates proper embryonic vascular patterning. J. Biol. Chem. 2013, 288, 2143-2156.

(C) 2013 by the authors; licensee MDPI, Basel, Switzerland. This article is an open access article distributed under the terms and conditions of the Creative Commons Attribution license (http://creativecommons.org/licenses/by/3.0/). 